\title{
Article \\ Study on Catalytic Water Oxidation Properties of Polynuclear Manganese Containing Polyoxometalates
}

\author{
Yue $W u *$, Jianye Pei, Xiaoxia Yu and Lihua Bi *
}

check for

updates

Citation: Wu, Y.; Pei, J.; Yu, X.; Bi, L. Study on Catalytic Water Oxidation

Properties of Polynuclear Manganese Containing Polyoxometalates.

Catalysts 2022, 12, 160. https:/ / doi.org/10.3390/catal12020160

Academic Editor: Gilles Berhault

Received: 24 December 2021

Accepted: 25 January 2022

Published: 27 January 2022

Publisher's Note: MDPI stays neutral with regard to jurisdictional claims in published maps and institutional affiliations.

Copyright: (C) 2022 by the authors. Licensee MDPI, Basel, Switzerland. This article is an open access article distributed under the terms and conditions of the Creative Commons Attribution (CC BY) license (https:// creativecommons.org/licenses/by/ $4.0 /)$.
College of Chemistry, Jilin University, Changchun 130012, China; peijy20@mails.jlu.edu.cn (J.P.); yuxx19@mails.jlu.edu.cn (X.Y.)

* Correspondence: wuyue17@mails.jlu.edu.cn (Y.W.); blh@jlu.edu.cn (L.B.)

Abstract: Splitting of water to produce hydrogen and oxygen is a green and effective method to produce clean energy. Finding an efficient water decomposition catalyst is the key step to realize water decomposition. In this work, by choosing from the literature, six polynuclear manganese $(\mathrm{Mn})$ containing polyoxometalates (Mn-POMs) with different $\mathrm{Mn}-\mathrm{O}$ clusters and oxidation states of $\mathrm{Mn},\left[\mathrm{Mn}^{\mathrm{II}} \mathrm{Mn}^{\mathrm{III}} \mathrm{SiW}_{10} \mathrm{O}_{37}(\mathrm{OH})\left(\mathrm{H}_{2} \mathrm{O}\right)\right]^{6-}\left(\mathrm{Mn}_{2}-\mathrm{POM}\right),\left[\mathrm{Mn}_{3}{ }_{3} \mathrm{Mn}^{\mathrm{III}}\left(\mathrm{H}_{2} \mathrm{O}\right)_{2}\left(\mathrm{PW}_{9} \mathrm{O}_{34}\right)_{2}\right]^{9-}$ $\left(\mathrm{Mn}_{4}-\mathrm{POM}\right),\left[\mathrm{Mn}_{4}{ }_{4} \mathrm{Mn}^{\mathrm{III}}{ }_{2} \mathrm{Ge}_{3} \mathrm{~W}_{24} \mathrm{O}_{94}\left(\mathrm{H}_{2} \mathrm{O}\right)_{2}\right]^{18-}\left(\mathrm{Mn}_{6}-\mathrm{POM}-1\right),\left[\mathrm{Mn}^{\mathrm{III}}{ }_{2} \mathrm{Mn}^{\mathrm{II}}{ }_{4}\left(\mu_{3}-\mathrm{O}\right)_{2}\left(\mathrm{H}_{2} \mathrm{O}\right)_{4}(\mathrm{~B}-\beta-\right.$ $\left.\left.\mathrm{SiW}_{8} \mathrm{O}_{31}\right)\left(\mathrm{B}-\beta-\mathrm{SiW}_{9} \mathrm{O}_{34}\right)\left(\gamma-\mathrm{SiW}_{10} \mathrm{O}_{36}\right)\right]^{18-}\left(\mathrm{Mn}_{6}-\mathrm{POM}-4\right),\left[\left\{\mathrm{Mn}_{3}^{\mathrm{III}} \mathrm{Mn}^{\mathrm{IV}}{ }_{4} \mathrm{O}_{4}(\mathrm{OH})_{2}\left(\mathrm{OH}_{2}\right)\right\}_{2}\left(\mathrm{~W}_{6} \mathrm{O}_{22}\right)\right.$ $\left.\left(\mathrm{H}_{2} \mathrm{~W}_{8} \mathrm{O}_{32}\right)_{2}\left(\mathrm{H}_{4} \mathrm{~W}_{13} \mathrm{O}_{46}\right)_{2}\right]^{26-}\left(\mathrm{Mn}_{14}-\mathrm{POM}\right)$, [ $\left.\mathrm{Mn}_{19}^{\mathrm{II}}(\mathrm{OH})_{12}\left(\mathrm{SiW}_{10} \mathrm{O}_{37}\right)_{6}\right]^{34-}\left(\mathrm{Mn}_{19}-\mathrm{POM}\right)$ were prepared. First, the catalytic performance towards the water oxidation of six Mn-POMs was investigated in solution for the first time. Second, six Mn-POMs were fabricated on the surface of ITO electrode using layer-by-layer self-assembly (LBL) to form the composite films, which were characterized by UV-vis spectroscopy and cyclic voltammetry, and then the catalytic water oxidation performance of the composite films was studied and compared with that in solution via a series of controlled experiments, the results indicate that the Mn-POMs with three-dimensional structures, which contain variable valence Mn-O cluster similar to the structure of photocatalytic active center (PSII) exhibit better catalytic performance.

Keywords: manganese; polyoxometalates; OER; catalyst; electrochemistry

\section{Introduction}

In recent years, global warming has led to the continuous deterioration of the human living environment. COVID-19 has also impacted global trade, exacerbating the impact of the energy crisis on social life. The attention and demand of the international community for clean energy are increasing. Hydrogen energy is recognized as a clean energy source, and its combustion product is water. At present, hydrogen production by cracking fossil fuels is widely used, which also causes secondary emissions of greenhouse gases and a decrease in the quantity of fossil fuels. Therefore, if water (the largest potential hydrogen energy provider) can be split to produce hydrogen, a green and recyclable clean energy system will be established. However, there are some problems to be solved, such as high energy consumption and high operation cost. Therefore, it is very necessary to develop fast, economical and reliable catalysts.

POMs are metal oxygen cluster compounds composed of transition metal atoms (M) and oxygen atoms $(\mathrm{O})$ connected by $\mathrm{MO}_{\mathrm{x}}$ polyhedra (tetrahedra, octahedra and icosahedra) in the way of common angle and common edge [1]. Because of this, the structures of POMs are changeable. The properties of POMs can be changed by adjusting the type and structure of transition metals. Heteropoly acids containing heteroatoms have richer structures due to the introduction of heteroatoms. POMs have excellent catalytic performance and reversible redox activity. They can be the potential catalysts for water cracking. At present, heteropoly acids containing ruthenium [2], manganese [3], cobalt, 
nickel and copper [4] have been proved to catalyze the decomposition of water. Compared with precious metal substituted polyacids, manganese, cobalt, nickel, iron and other metal substituted POMs are cheap and have a wider range of applications. Among them, the Mn-O clusters in Mn-POM have the same composition or structure as the photosynthetic center of green plants [5]. Therefore, we focus on the research of Mn containing POM catalysts. There are dozens of Mn containing POMs ranging from 1 to $40[3,6]$. At present, the catalytic water oxidation properties of some manganese containing POMs have been studied separately [7-12], the effects of amount, oxidation state of Mn ions and $\mathrm{Mn}-\mathrm{O}$ cluster structure on the catalytic performance for water decomposition have hardly been reported. In order to select Mn-POMs with good catalytic performance, and find the influence of amount, oxidation state and $\mathrm{Mn}-\mathrm{O}$ cluster structure, we selected six $\mathrm{Mn}_{\mathrm{x}} \mathrm{POMs}$ as representative for comparison, including two manganese containing POMs: $\left[\mathrm{Mn}^{\mathrm{II}} \mathrm{Mn}^{\mathrm{III}} \mathrm{SiW}_{10} \mathrm{O}_{37}(\mathrm{OH})\left(\mathrm{H}_{2} \mathrm{O}\right)\right]^{6-}\left(\mathrm{Mn}_{2}-\mathrm{POM}\right)[13]$ and four manganese containing POM: [ $\left.\mathrm{Mn}_{3}{ }_{3} \mathrm{Mn}^{\mathrm{III}}\left(\mathrm{H}_{2} \mathrm{O}\right)_{2}\left(\mathrm{PW}_{9} \mathrm{O}_{34}\right)_{2}\right]^{9-}\left(\mathrm{Mn}_{4}-\mathrm{POM}\right)$ [14], six manganese containing POMs: $\left[\mathrm{Mn}_{4} \mathrm{Mn}^{\mathrm{III}}{ }_{2} \mathrm{Ge}_{3} \mathrm{~W}_{24} \mathrm{O}_{94}\left(\mathrm{H}_{2} \mathrm{O}\right)_{2}\right]^{18-}\left(\mathrm{Mn}_{6}-\mathrm{POM}-1\right)$ [15], [ $\mathrm{Mn}^{\mathrm{III}}{ }_{2} \mathrm{Mn}_{4}{ }_{4}\left(\mu_{3}-\mathrm{O}\right)_{2}\left(\mathrm{H}_{2} \mathrm{O}\right)_{4}(\mathrm{~B}-\beta-$ $\left.\left.\mathrm{SiW}_{8} \mathrm{O}_{31}\right)\left(\mathrm{B}-\beta-\mathrm{SiW}_{9} \mathrm{O}_{34}\right)\left(\gamma-\mathrm{SiW}_{10} \mathrm{O}_{36}\right)\right]^{18-}\left(\mathrm{Mn}_{6}-\mathrm{POM}-4\right)$ [16], 14 manganese containing POM: [ $\left.\left\{\mathrm{Mn}^{\mathrm{III}}{ }_{3} \mathrm{Mn}^{\mathrm{IV}}{ }_{4} \mathrm{O}_{4}(\mathrm{OH})_{2}\left(\mathrm{OH}_{2}\right)\right\}_{2}\left(\mathrm{~W}_{6} \mathrm{O}_{22}\right)\left(\mathrm{H}_{2} \mathrm{~W}_{8} \mathrm{O}_{32}\right)_{2}\left(\mathrm{H}_{4} \mathrm{~W}_{13} \mathrm{O}_{46}\right)_{2}\right]^{26-}\left(\mathrm{Mn}_{14}-\mathrm{POM}\right)$ [17] and 19 manganese containing POM $\left[\mathrm{Mn}_{19}{ }_{19}(\mathrm{OH})_{12}\left(\mathrm{SiW}_{10} \mathrm{O}_{37}\right)_{6}\right]^{34-}\left(\mathrm{Mn}_{19}-\mathrm{POM}\right)$ [18]. It is hoped that certain laws can be found for researchers' reference.

$\mathrm{Mn}_{2}-\mathrm{POM}$ is synthesized by one pot method from $\mathrm{Mn}\left(\mathrm{CH}_{3} \mathrm{COO}\right)_{2} \cdot 4 \mathrm{H}_{2} \mathrm{O}, \mathrm{Na}_{10}$ [a$\left.\mathrm{SiW}_{9} \mathrm{O}_{34}\right] \cdot 15 \mathrm{H}_{2} \mathrm{O}$ and $\mathrm{KCl}$ at $80^{\circ} \mathrm{C}$ [13]. The compound is a one-dimensional chain structure formed by Keggin type units containing two manganese, in which one manganese is divalent and one manganese is trivalent. The structure is shown in Figure 1a.

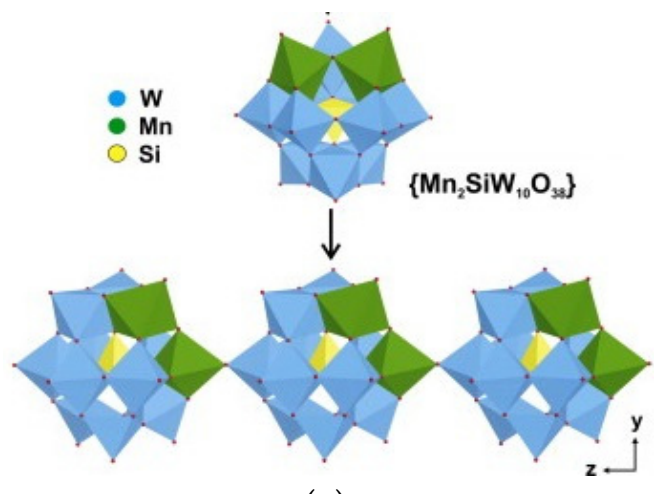

(a)

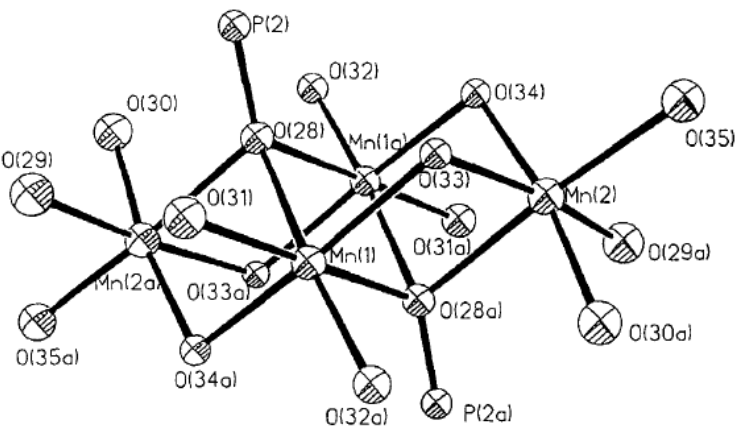

(b)

Figure 1. (a) Hypothetical formation sequence for chains of $\left[\mathrm{Mn}^{2+} \mathrm{Mn}^{3+} \mathrm{SiW}_{10} \mathrm{O}_{38}\right]^{7-}$ building blocks linked via $\mathrm{Mn}-\mathrm{O}-\mathrm{W}$ bridges along $\mathrm{c}$ (blue $=\mathrm{WO}_{6}$ octahedra, green $=\mathrm{MnO}_{6}$ octahedra, yellow $=\mathrm{SiO}_{4}$ tetrahedra). Reprinted with permission from ref. [13]. Copyright 2013 Elsevier Ltd.; (b) The tetramanganese unit of $\left[\mathrm{Mn}_{4}\left(\mathrm{H}_{2} \mathrm{O}\right)_{2}\left(\mathrm{PW}_{9} \mathrm{O}_{34}\right)_{2}\right]^{9-}$ showing atomic labels. Reprinted with permission from ref. [14]. Copyright 1995 Elsevier Science Ltd.

$\mathrm{Mn}_{4}-\mathrm{POM}$ was synthesized from precursors $\mathrm{K}_{10}\left[\mathrm{Mn}_{4}\left(\mathrm{H}_{2} \mathrm{O}\right)_{2}\left(\mathrm{PW}_{9} \mathrm{O}_{34}\right)_{2}\right] \cdot 41 \mathrm{H}_{2} \mathrm{O}$ and $\mathrm{K}_{2} \mathrm{~S}_{2} \mathrm{O}_{8}$ at $85^{\circ} \mathrm{C}$ [14]. Multiple Mn-O-Mn bonds are formed between Mn atoms in the compound, and the positions of four manganese are close to the plane, of which three manganese are divalent and one manganese is trivalent. The structure is shown in Figure $1 \mathrm{~b}$.

$\mathrm{Mn}_{6}-\mathrm{POM}-1$ was synthesized from $\mathrm{Na}_{2} \mathrm{WO}_{4}, \mathrm{GeO}_{2}, \mathrm{HCl}, \mathrm{Mn}\left(\mathrm{CH}_{3} \mathrm{COO}\right)_{2} \cdot 4 \mathrm{H}_{2} \mathrm{O}$ and imidazole at $90{ }^{\circ} \mathrm{C}$ [15]. The compound is composed of two Keggin units with three manganese substituted $\left[\mathrm{Mn}_{3} \mathrm{GeW}_{9} \mathrm{O}_{34}\right]^{4-}$ and a six-vacancy bridged cluster $\left[\mathrm{GeW}_{6} \mathrm{O}_{26}\right]^{12-}$. The structure is shown in Figure 2a, in which each Keggin unit species substituted by $\left[\mathrm{Mn}_{3} \mathrm{GeW}_{9} \mathrm{O}_{34}\right]^{4-}$ contains two divalent manganese and one trivalent manganese. 


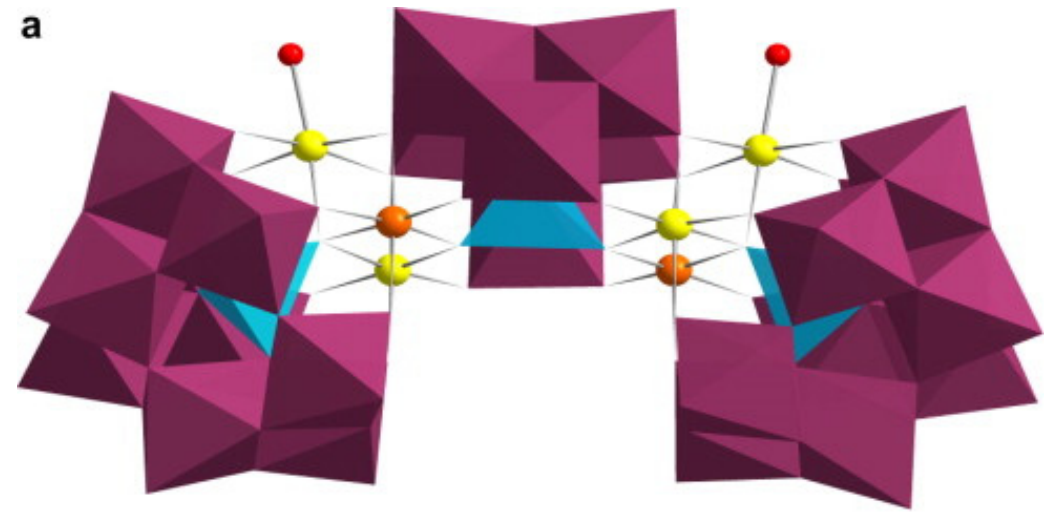

b

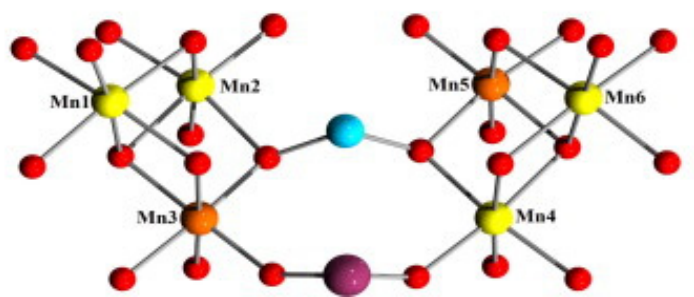

Figure 2. (a) Structure of the $\left[\mathrm{Mn}_{6} \mathrm{Ge}_{3} \mathrm{~W}_{24} \mathrm{O}_{94}\left(\mathrm{H}_{2} \mathrm{O}\right)_{2}\right]^{18-}$ polyanion. Plum octahedra, $\left\{\mathrm{WO}_{6}\right\}$; sky blue tetrahedra, $\left\{\mathrm{GeO}_{4}\right\}$; yellow ball, $\mathrm{Mn}^{\mathrm{II}}$; orange ball, $\mathrm{Mn}^{\mathrm{III}}$. (b) Structure of $\mathrm{Mn}_{6}$ unit. Reprinted with permission from ref. [15]. Copyright 2009 Elsevier B.V.

$\mathrm{Mn}_{6}$-POM-4 was synthesized from $\mathrm{K}_{8}\left[\gamma-\mathrm{SiW}_{10} \mathrm{O}_{36}\right] \cdot 12 \mathrm{H}_{2} \mathrm{O}, \mathrm{MnCl}_{2}$ and $\mathrm{K}_{2} \mathrm{CO}_{3}$ at $40{ }^{\circ} \mathrm{C}$. The compound consists of three inequivalent silicotungstate Keggin fragments ( $\left.\left\{\mathrm{SiW}_{8}\right\},\left\{\mathrm{SiW}_{9}\right\},\left\{\mathrm{SiW}_{10}\right\}\right)$ and $\left\{\mathrm{Mn}_{4} \mathrm{O}_{4}\right\}$ cubane core with an appended "pendant" Mn ion. The structure of $\left\{\mathrm{Mn}_{4} \mathrm{O}_{4}\right\}$ cubane core is very similar to that of PSII [16]. The compound was previously confirmed by our research group to have the ability of photo-electrocatalytic water decomposition [19]. The structure is shown in Figure 3. The compound contains four divalent manganese and two trivalent manganese.

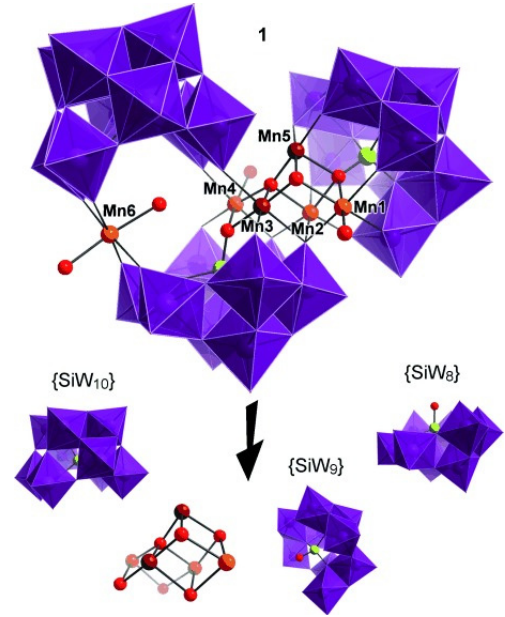

(a)

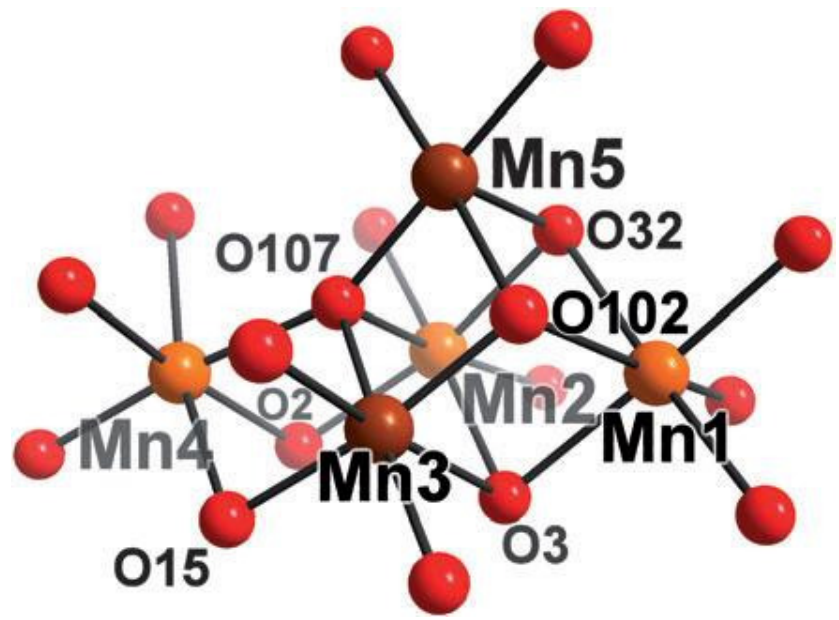

(b)

Figure 3. (a) Structure of $\left[\mathrm{Mn}^{\mathrm{III}}{ }_{2} \mathrm{Mn}_{4}{ }_{4}\left(\mu_{3}-\mathrm{O}\right)_{2}\left(\mathrm{H}_{2} \mathrm{O}\right)_{4}\left(\mathrm{~B}-\beta-\mathrm{SiW}_{8} \mathrm{O}_{31}\right)\left(\mathrm{B}-\beta-\mathrm{SiW}_{9} \mathrm{O}_{34}\right)\left(\gamma-\mathrm{SiW}_{10} \mathrm{O}_{36}\right)\right]^{18-}$. $\mathrm{WO}_{6}$ purple polyhedra, $\mathrm{Mn}$ orange and brown, Si green, $\mathrm{O}$ red. (b) The $\left\{\mathrm{Mn}_{5} \mathrm{O}_{6}\right\}$ cubane core of 1 , described as an appended $\left[\mathrm{Mn}^{\mathrm{III}}{ }_{2} \mathrm{Mn}_{2}{ }_{2} \mathrm{O}_{4}\right]^{2+}$ cubane where Mn1, Mn2, Mn3, Mn5 are connected to manganese atom Mn4 through oxygen atom $\mathrm{O} 107$ from the cube and oxygen atoms $\mathrm{O} 2$ and $\mathrm{O} 15$ of the $\left\{\mathrm{SiW}_{9}\right\}$ cluster. $\mathrm{Mn}^{\mathrm{II}}$ orange, $\mathrm{Mn}^{\mathrm{III}}$ brown, O red. Reprinted with permission from ref. [16] Copyright 2011 John Wiley and Sons. 
$\mathrm{Mn}_{14}$-POM was synthesized from precursors $\mathrm{Mn}_{12}$-acetate, $\mathrm{Na}_{2} \mathrm{WO}_{4}, \mathrm{NaOAc} \cdot 3 \mathrm{H}_{2} \mathrm{O}$, $\mathrm{HCl}$ and dimethylamine hydrochloride at $100{ }^{\circ} \mathrm{C}$. The compound contains a total of $14 \mathrm{Mn}$ centers, which are divided into a pair of $\mathrm{Mn}_{7}$ cores. Each core is embedded in the shell of diamagnetic isopolytungstate ligand and well separated from the other [17]. The structure of $\mathrm{Mn}_{7}$ is shown in Figure 4. Each $\mathrm{Mn}_{7}$ includes a $\left[\mathrm{Mn}^{\mathrm{IV}}{ }_{4} \mathrm{O}_{4}\right]^{8+}$ cubic unit, and three $\mathrm{Mn}^{\mathrm{III}}$ are connected at the periphery. The compound contains 8 tetravalent manganese and 6 trivalent manganese.

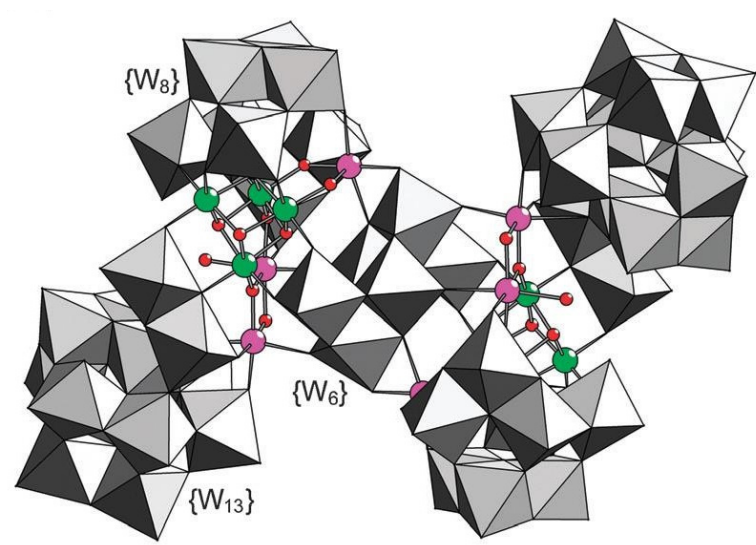

(a)

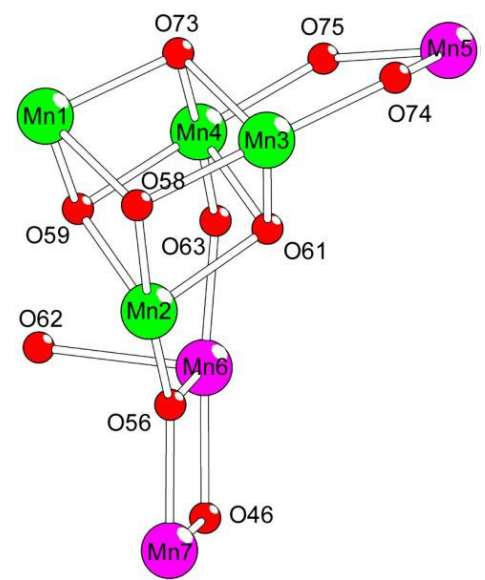

(b)

Figure 4. (a) Structure of $\mathrm{Mn}_{14}$-POM. $\mathrm{Mn}^{\mathrm{III}}$, purple; $\mathrm{Mn}^{\mathrm{IV}}$, green; $\mathrm{WO}_{6}$, gray octahedra; $\mathrm{O}$, red. (b) Magnetic cores of $\mathrm{Mn}_{7}$. Reprinted with permission from ref. [17] Copyright The Royal Society of Chemistry 2011.

$\mathrm{Mn}_{19}$-POM was synthesized from $\mathrm{MnCl}_{2} \cdot 4 \mathrm{H}_{2} \mathrm{O}, \mathrm{Na}_{10}\left[\mathrm{~A}-\alpha-\mathrm{SiW}_{9} \mathrm{O}_{34}\right], \mathrm{NaOH}, \mathrm{Na}_{3} \mathrm{PO}_{4}$ and $\mathrm{HCl}$ at $70{ }^{\circ} \mathrm{C} \mathrm{[18].} \mathrm{The} \mathrm{structure} \mathrm{is} \mathrm{shown} \mathrm{in} \mathrm{Figure} \mathrm{5.} \mathrm{All} 19 \mathrm{Mn}^{\mathrm{II}}$ ions are located on the same plane to form a hexagonal structure based on edge shared $\mathrm{MnO}_{6}$ octahedron.
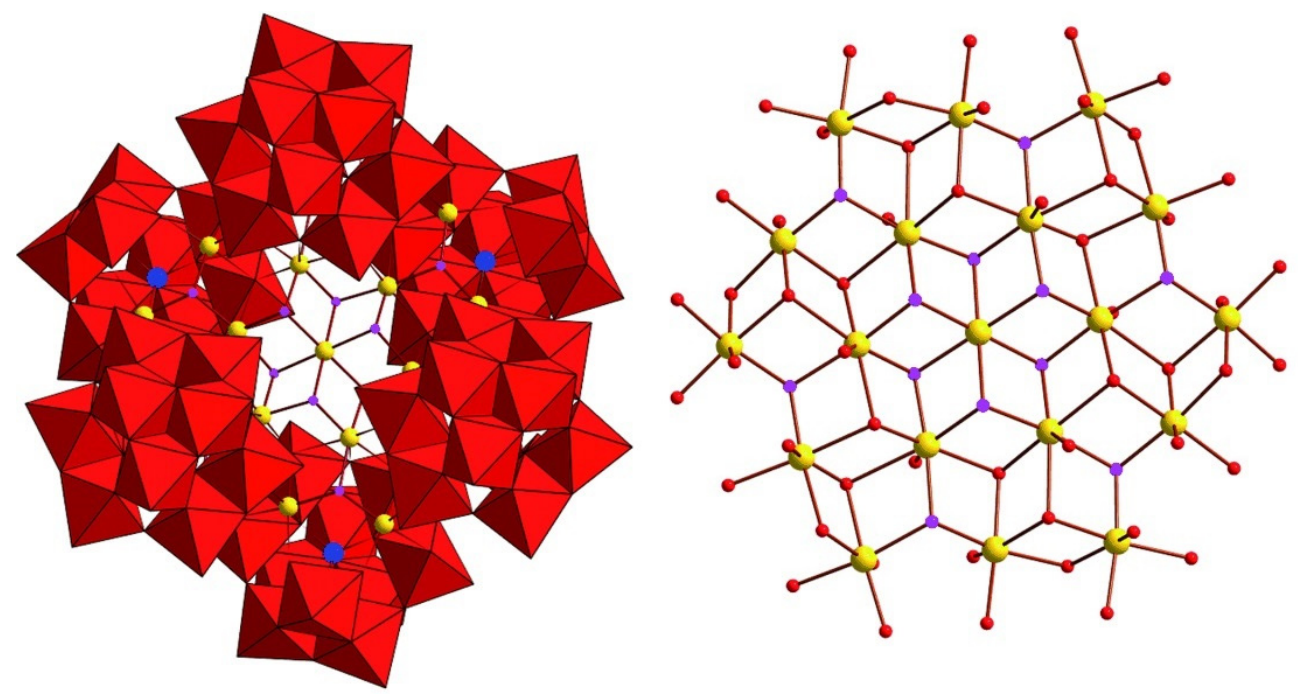

Figure 5. Structure of the $\mathrm{Mn}_{19}$-oxo-hydroxo core in $\mathrm{Mn}_{19}$-POM. Protonated oxygen atoms are shown in pink. $\mathrm{WO}_{6}$ red octahedra, Si blue balls, Mn yellow balls, $\mathrm{O}$ red balls. Reprinted with permission from ref. [18]. Copyright 2011 Wiley-VCH Verlag GmbH \& Co. KGaA, Weinheim. 
In order to more intuitively understand the valence of $\mathrm{Mn}$ ions in $\mathrm{Mn}_{\mathrm{x}} \mathrm{POMs}$, we summarize it in Table 1.

Table 1. Summary of Mn ion valence in $\mathrm{Mn}_{\mathrm{x}} \mathrm{POMs}$.

\begin{tabular}{|c|c|c|c|c|c|}
\hline Abbreviation & Chemical Formula & $\mathbf{N}\left(\mathbf{M n}^{\mathrm{II}}\right)$ & $\mathbf{N}\left(\mathrm{Mn}^{\mathrm{III}}\right)$ & $\mathbf{N}\left(\mathbf{M n}^{\mathrm{IV}}\right)$ & Total N (Mn) \\
\hline $\mathrm{Mn}_{2}-\mathrm{POM}$ & {$\left[\mathrm{Mn}^{\mathrm{II}} \mathrm{Mn}^{\mathrm{III}} \mathrm{SiW}_{10} \mathrm{O}_{37}(\mathrm{OH})\left(\mathrm{H}_{2} \mathrm{O}\right)\right]^{6-}$} & 1 & 1 & 0 & 2 \\
\hline $\mathrm{Mn}_{4}-\mathrm{POM}$ & {$\left[\mathrm{Mn}_{3}{ }_{3}^{\mathrm{M}} \mathrm{Mn}^{\mathrm{III}}\left(\mathrm{H}_{2} \mathrm{O}\right)_{2}\left(\mathrm{PW}_{9} \mathrm{O}_{34}\right)_{2}\right]^{9-}$} & 3 & 1 & 0 & 4 \\
\hline $\mathrm{Mn}_{6}-\mathrm{POM}-1$ & {$\left[\mathrm{Mn}_{4}{ }_{4} \mathrm{Mn}^{\mathrm{III}}{ }_{2} \mathrm{Ge}_{3} \mathrm{~W}_{24} \mathrm{O}_{94}\left(\mathrm{H}_{2} \mathrm{O}\right)_{2}\right]^{18-}$} & 4 & 2 & 0 & 6 \\
\hline $\mathrm{Mn}_{6}-\mathrm{POM}-4$ & $\begin{array}{c}{\left[\mathrm{Mn}_{2}^{\mathrm{III}}{ }_{2} \mathrm{Mn}_{4}^{\mathrm{II}}\left(\mu_{3}-\mathrm{O}\right)_{2}\left(\mathrm{H}_{2} \mathrm{O}\right)_{4}\left(\mathrm{~B}-\beta-\mathrm{SiW}_{8} \mathrm{O}_{31}\right)\left(\mathrm{B}-\beta-\mathrm{SiW}_{9} \mathrm{O}_{34}\right)(\gamma-\right.} \\
\left.\left.\mathrm{SiW}_{10} \mathrm{O}_{36}\right)\right]^{18-}\end{array}$ & 4 & 2 & 0 & 6 \\
\hline $\mathrm{Mn}_{14}-\mathrm{POM}$ & {$\left[\left\{\mathrm{Mn}^{\mathrm{IIII}}{ }_{3} \mathrm{Mn}^{\mathrm{IV}}{ }_{4} \mathrm{O}_{4}(\mathrm{OH})_{2}\left(\mathrm{OH}_{2}\right)\right\}_{2}\left(\mathrm{~W}_{6} \mathrm{O}_{22}\right)\left(\mathrm{H}_{2} \mathrm{~W}_{8} \mathrm{O}_{32}\right)_{2}\left(\mathrm{H}_{4} \mathrm{~W}_{13} \mathrm{O}_{46}\right)_{2}\right]^{26-}$} & 0 & 6 & 8 & 14 \\
\hline $\mathrm{Mn}_{19}-\mathrm{POM}$ & {$\left[\mathrm{Mn}_{19}(\mathrm{OH})_{12}\left(\mathrm{SiW}_{10} \mathrm{O}_{37}\right)_{6}\right]^{34-}$} & 19 & 0 & 0 & 19 \\
\hline
\end{tabular}

\section{Results and Discussion}

\subsection{Structural Analysis}

\subsubsection{Infrared Spectrum (IR) Test}

In order to verify that the $\mathrm{Mn}_{\mathrm{x}} \mathrm{POMs}$ were synthesized according to the literature, their infrared spectra were measured. As shown in Figure 6, we can observe the main characteristic vibration frequencies at 991, 945, 898, 779 and $710 \mathrm{~cm}^{-1}$ (as shown in Figure 6a), four weak peaks at 662, 642, 538 and 480 (internal diagram in Figure 6a); the main characteristic vibration frequencies at 1105, 1060, 944,778,620, 592 and $500 \mathrm{~cm}^{-1}$ (as shown in Figure $6 \mathrm{~b}$ ); the main characteristic vibration frequencies at 941, 875, 770, 696 and 458 and the weak peaks at $509 \mathrm{~cm}^{-1}$ (as shown in Figure 6c); the main characteristic vibration frequencies at 1626 , $940,877,775,725$ and $509 \mathrm{~cm}^{-1}$ (as shown in Figure $6 \mathrm{~d}$ ); the main characteristic vibration frequencies at 1629,1465, 1438,1408,1385, 1020, 943 and $750 \mathrm{~cm}^{-1}$; and the weak peaks at $676,631,597,569,487$ and $467 \mathrm{~cm}^{-1}$ in the illustration (as shown in Figure 6e); The main characteristic vibration frequencies at 988, 945, 895, 793, 711, 646 and $536 \mathrm{~cm}^{-1}$ (as shown in Figure 6f) are consistent with the infrared characteristic peaks of $\mathrm{Mn}_{2}-\mathrm{POM}$ [13], $\mathrm{Mn}_{4}$-POM [14,20], Mn 6 -POM-1 [15], Mn 6 -POM-4 [16], Mn 14 -POM [17] and $\mathrm{Mn}_{19}-\mathrm{POM}$ [18] in the literature, which proves that we have successfully prepared the above six $\mathrm{Mn}_{\mathrm{x}} \mathrm{POMs}$. There are some small differences between the measured and reported values, which may be caused by the different instrument used.

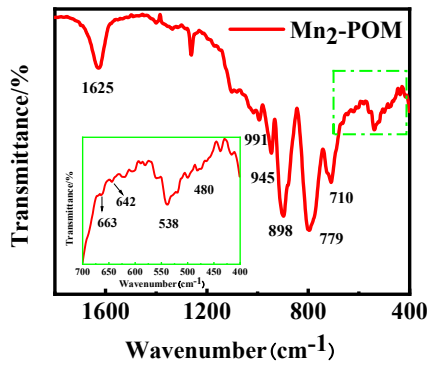

(a)

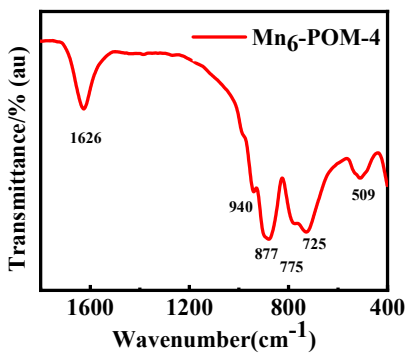

(d)

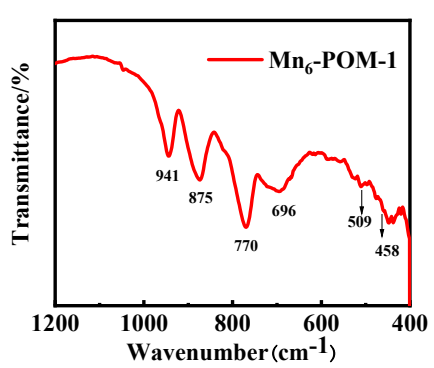

(b)

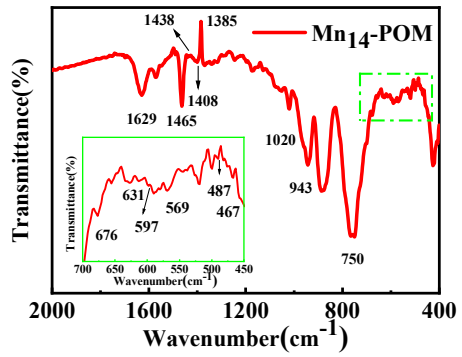

(e)

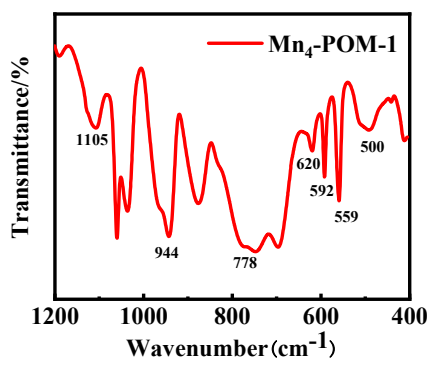

(c)

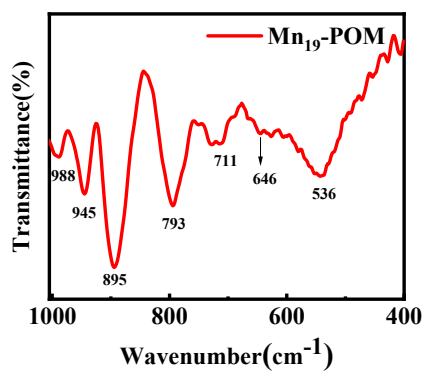

(f)

Figure 6. The IR spectra of (a) $\mathrm{Mn}_{2}-\mathrm{POM}$, (b) $\mathrm{Mn}_{4}-\mathrm{POM}$, (c) $\mathrm{Mn}_{6}-\mathrm{POM}-1$, (d) $\mathrm{Mn}_{6}-\mathrm{POM}-4$, (e) $\mathrm{Mn}_{14}-\mathrm{POM}$ and (f) $\mathrm{Mn}_{19}$-POM. 


\subsubsection{X-ray Transmission Spectroscopy}

In order to deeply understand the composition of $\mathrm{Mn}_{\mathrm{X}}-\mathrm{POMs}$ and prove that they were successfully assembled on ITO, the XPS of six $\mathrm{Mn}_{\mathrm{X}}$-POMs films electrodes were tested. As shown in Figures S3-S8, according to the high-resolution spectra, we can confirm that $\mathrm{Mn}, \mathrm{Si}, \mathrm{W}$ and $\mathrm{O}$ elements appear in $\mathrm{Mn}_{2}-\mathrm{POM}$ (Figure S3), $\mathrm{Mn}_{6}-\mathrm{POM}-4$ (Figure S6) and $\mathrm{Mn}_{19}-\mathrm{POM}$ (Figure S8), Mn, P, W and $\mathrm{O}$ appear in $\mathrm{Mn}_{4}-\mathrm{POM}$ (Figure S4), Mn, Ge, $\mathrm{W}$ and $\mathrm{O}$ appear in $\mathrm{Mn}_{6}-\mathrm{POM}-1$ (Figure S5), and $\mathrm{Mn}, \mathrm{W}$ and $\mathrm{O}$ appear in $\mathrm{Mn}_{14}-\mathrm{POM}$ (Figure S7). The XPS spectra of N1s and Cl2p in Figures S4a and S8a belong to PDDA and PSS. Figure S7c is the Mn2p diagram of $\left[\mathrm{Mn}_{14}-\mathrm{POM}\right]_{5}$. There is a narrow peak at $644 \mathrm{eV}$ binding energy, corresponding to $\mathrm{Mn}^{4+}$ [21], which proves the existence of $\mathrm{Mn}^{4+}$ in $\mathrm{Mn}_{14}$-POM. Figures S3-S6c have a wide Mn2 $\mathrm{p}_{3 / 2}$ peak at 638 to $644 \mathrm{eV}$, which is different from the narrow peak shown in Figure $S 8 \mathrm{c}$ at $640.5 \mathrm{eV}$, which indicates the presence of is $\mathrm{Mn}^{2+}$. For the former, there is a wide peak due to the presence of $\mathrm{Mn}^{2+}$ and $\mathrm{Mn}^{3+}$ in a compound.

\subsection{Electrochemical Characteristics}

\subsubsection{Cyclic Voltammetry}

In order to further verify that $\mathrm{Mn}_{\mathrm{x}} \mathrm{POMs}$ were correctly prepared, the electrochemical behavior of $\mathrm{Mn}_{\mathrm{x}} \mathrm{POMs}$ in solution was studied by cyclic voltammetry (CV). In Figure 7a, it is found that there are two oxidation peaks of $\mathrm{Mn}_{2}-\mathrm{POM}$ at 0.5 and $1.2 \mathrm{~V}$ potentials, which are the oxidation peaks of $\mathrm{Mn}^{2+/ 3+}$ and $\mathrm{Mn}^{3+/ 4+}$ respectively. At the same time, there are three reduction peaks at 1.0, 0.85 and $0.4 \mathrm{~V}$, which are $\mathrm{Mn}^{4+/ 3+}, \mathrm{Mn}^{4+/ 2+}$ and $\mathrm{Mn}^{3+/ 2+}$ respectively. It is consistent with the literature. In Figure $7 \mathrm{~b}$, it is found that there a peak of $\mathrm{Mn}_{4}$-POM at $0.9 \mathrm{~V}$ of oxidation peaks of $\mathrm{Mn}^{2+/ 4+}$ and two reduction peaks at 1.1 , and $0.7 \mathrm{~V}$ which are $\mathrm{Mn}^{4+/ 3+}$ and $\mathrm{Mn}^{4+/ 2+}$ respectively. In Figure $7 \mathrm{c}$, it is found that an oxidation peaks of $\mathrm{Mn}_{6}-\mathrm{POM}-1$ at $0.75 \mathrm{~V}$ of oxidation peaks of $\mathrm{Mn}^{2+/ 4+}$ and two reduction peaks at 0.62 , and $0.4 \mathrm{~V}$ which are $\mathrm{Mn}^{4+/ 2+}$ and $\mathrm{Mn}^{3+/ 2+}$ respectively.

It can be observed from Figure $7 d$ that there are three obvious oxidation peaks at 0.3 , 0.65 and $1.1 \mathrm{~V}$, respectively corresponding to $\mathrm{Mn}^{2+/ 3+}, \mathrm{Mn}^{2+/ 4+}$ and $\mathrm{Mn}^{3+/ 4+}$. At the same time, there are three reduction peaks, at $1.1,0.75$ and $0.15 \mathrm{~V}$, which are $\mathrm{Mn}^{4+/ 3+}, \mathrm{Mn}^{4+/ 2+}$ and $\mathrm{Mn}^{3+/ 2+}$ respectively. It is consistent with the literature. It can be observed from Figure 7e that there is an obvious oxidation peak of $\mathrm{Mn}^{3+/ 4+}$ at $1.1 \mathrm{~V}$, and there are no other oxidation peaks, because the valence of $\mathrm{Mn}$ in $\mathrm{Mn}_{14}-\mathrm{POM}$ is trivalent and tetravalent, and there is no divalent manganese. This also confirmed that the synthetic product was $\mathrm{Mn}_{14}-\mathrm{POM}$. It can be observed from Figure $7 f$ that there are three obvious oxidation peaks at $0.53,0.88$ and $1.18 \mathrm{~V}$, respectively corresponding to $\mathrm{Mn}^{2+/ 3+}, \mathrm{Mn}^{2+/ 4+}$ and $\mathrm{Mn}^{3+/ 4+}$. At the same time, there are three reduction peaks, at 1.0, 0.7 and $0.4 \mathrm{~V}$, which are $\mathrm{Mn}^{4+/ 3+}, \mathrm{Mn}^{4+/ 2+}$ and $\mathrm{Mn}^{3+/ 2+}$ respectively. This confirms the existence of divalent manganese in $\mathrm{Mn}_{19}-\mathrm{POM}$. It is consistent with the literature.

It should be noted that in order to facilitate comparison with the literature, we conducted CVs test of $\mathrm{Mn}_{\mathrm{x}} \mathrm{POMs}$ according to the experimental conditions in the literature, resulting in differences in the experimental conditions between $\mathrm{Mn}_{\mathrm{x}} \mathrm{POMs}$, including $\mathrm{pH}, \mathrm{Mn}_{\mathrm{x}} \mathrm{POMs}$ concentration, scan rate, and the composition and concentration of buffer solution. Thus, redox potentials of Mn are different. 


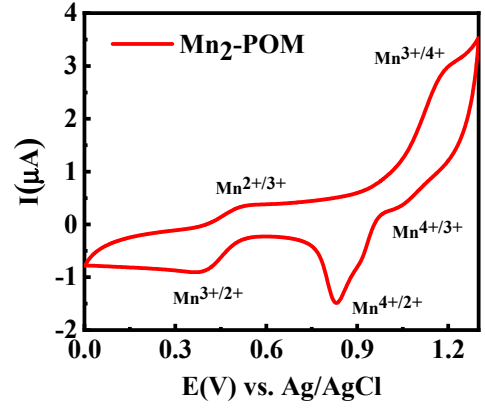

(a)

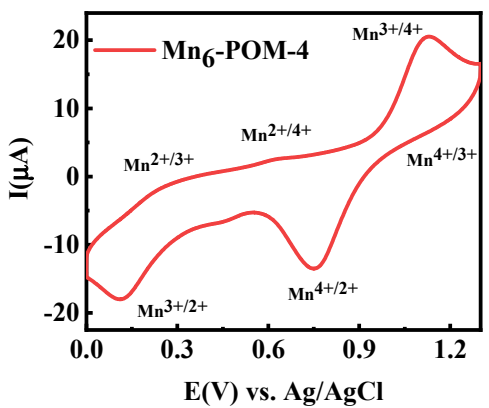

(d)

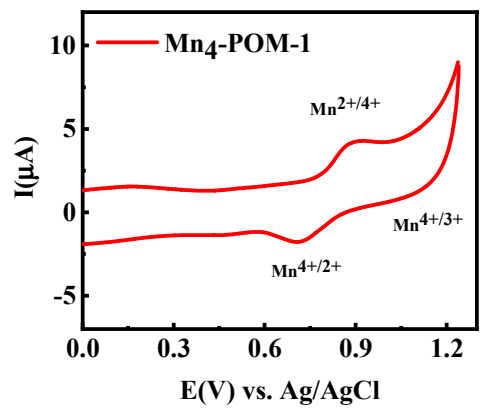

(b)

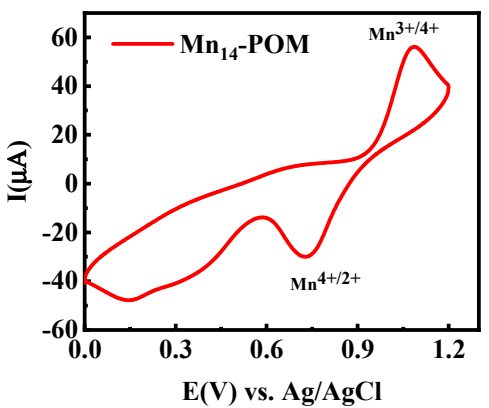

(e)

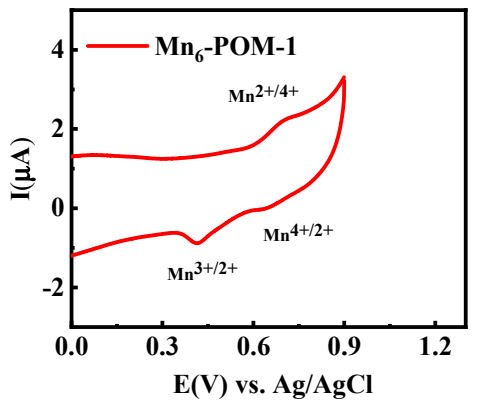

(c)

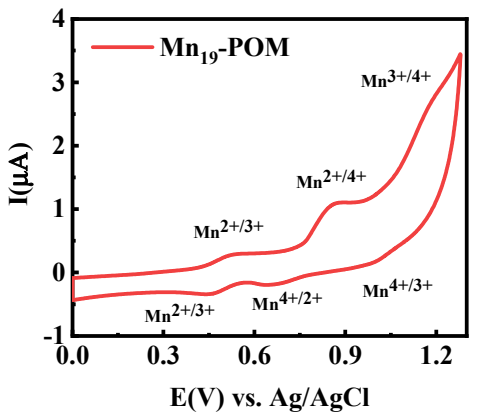

(f)

Figure 7. (a) CV curves of $\mathrm{Mn}_{2}-\mathrm{POM}(0.2 \mathrm{mM})$ in $\mathrm{pH} 3\left(0.5 \mathrm{M} \mathrm{Na}_{2} \mathrm{SO}_{4}+\mathrm{H}_{2} \mathrm{SO}_{4}\right)$, scan rate $25 \mathrm{mV} / \mathrm{s}$; (b) CV curves of $\mathrm{Mn}_{4}$-POM (0.1 mM) in pH 5 (0.5 M NaAc-HAc), scan rate $50 \mathrm{mV} / \mathrm{s}$; (c) CV curves of $\mathrm{Mn}_{6}$-POM-1 (0.1 mM) in pH 7 (0.5 M NaAc-HAc), scan rate $50 \mathrm{mV} / \mathrm{s}$; (d) CV curves of $\mathrm{Mn}_{6}-\mathrm{POM}-4$ $(0.1 \mathrm{mM})$ in pH 5 (0.5 M NaAc-HAc), scan rate $50 \mathrm{mV} / \mathrm{s}$; (e) CV curves of $\mathrm{Mn}_{14}-\mathrm{POM}(0.1 \mathrm{mM})$ in pH 5 (0.5 M NaAc-HAc), scan rate $50 \mathrm{mV} / \mathrm{s}$; (f) CV curves of $\mathrm{Mn}_{19}-\mathrm{POM}(0.04 \mathrm{mM})$ in pH 5 (1 M NaAc-HAc), scan rate $10 \mathrm{mV} / \mathrm{s}$.

\subsection{2. $\mathrm{pH}$}

In order to determine the optimal $\mathrm{pH}$ value of the subsequent catalytic experiment in aqueous solution and study the stability of the $\mathrm{Mn}_{\mathrm{x}} \mathrm{POMs}$ at different $\mathrm{pH}$, we tested the $\mathrm{CV}$ s of six $\mathrm{Mn}_{\mathrm{x}} \mathrm{POMs}$ at $\mathrm{pH}$ 5/6/7. As shown in Figure 8, most $\mathrm{Mn}_{\mathrm{x}} \mathrm{POM}$ s have obvious redox peaks at $\mathrm{pH} 5 / 6 / 7$, indicating that the $\mathrm{Mn}_{\mathrm{x}} \mathrm{POMs}$ are stable within this range, and the redox peak of $\mathrm{Mn}$ of the $\mathrm{Mn}_{\mathrm{x}} \mathrm{POMs}$ moves to the negative potential direction with the increase of $\mathrm{pH}$, indicating that there is proton migration in the redox process of $\mathrm{Mn}$. The redox peak of compound $\mathrm{Mn}_{19}$-POM decreases with the increase of $\mathrm{pH}$, indicating that the compound is relatively stable under acidic conditions.

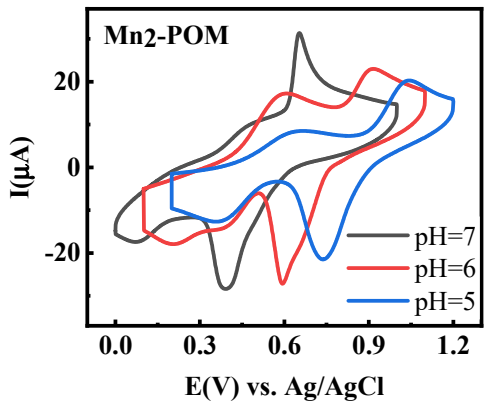

(a)

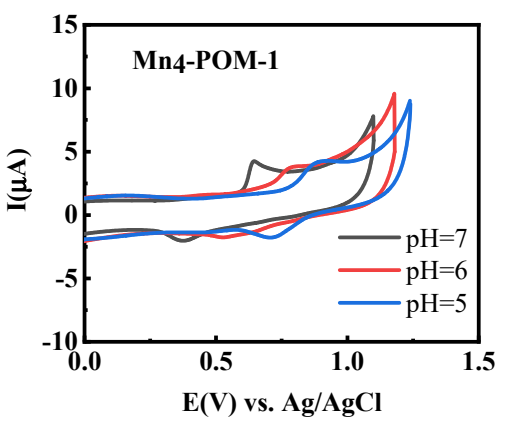

(b)

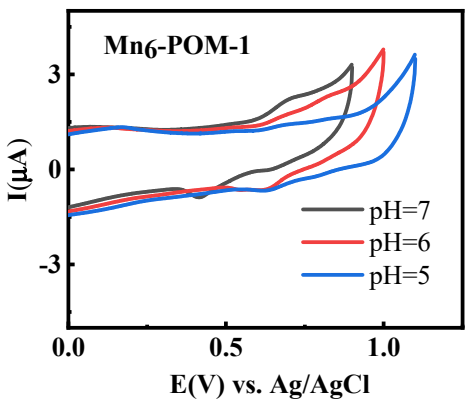

(c)

Figure 8. Cont. 


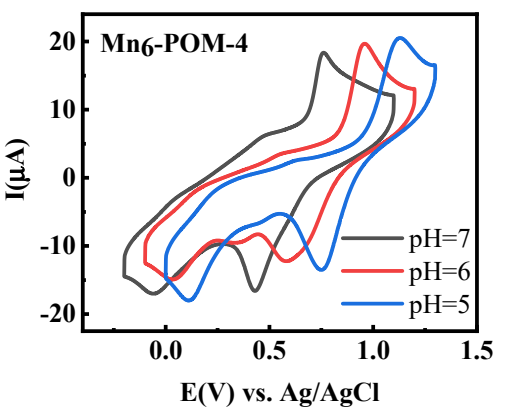

(d)

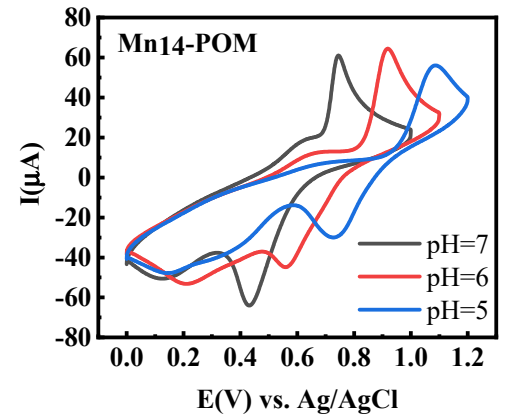

(e)

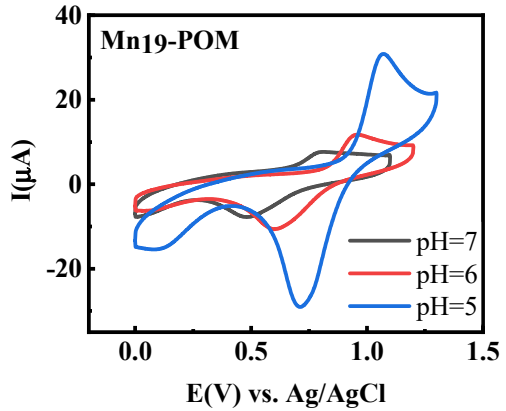

(f)

Figure 8. CV curves of $0.1 \mathrm{mM}$ (a) $\mathrm{Mn}_{2}-\mathrm{POM},(\mathbf{b}) \mathrm{Mn}_{4}-\mathrm{POM}$, (c) $\mathrm{Mn}_{6}-\mathrm{POM}-1$, (d) $\mathrm{Mn}_{6}-\mathrm{POM}-4$, (e) $\mathrm{Mn}_{14}$-POM and (f) $\mathrm{Mn}_{19}$-POM in NaAc/HAc buffer $(0.5 \mathrm{M})$ at different $\mathrm{pH}(5 / 6 / 7)$, scan rate $50 \mathrm{mV} / \mathrm{s}$.

\subsection{Assembly of Thin Film Electrode}

We use the layer by layer assembly method to assemble the $\mathrm{Mn}_{\mathrm{x}} \mathrm{POMs}$ to the ITO electrode surface. See Section 3.3 for the assembly method. In order to verify the repeatability of the assembly method, we monitored the UV-Vis absorption of the films during the assembly process. At the same time, we also carried out secondary verification by electrochemical means.

\section{UV-Vis Absorption Spectrum Test}

As can be seen from Figure $\mathrm{S} 1 \mathrm{a}, \mathrm{Mn}_{\mathrm{x}} \mathrm{POMs}$ has an absorption peak in the ultraviolet range of 243 to $257 \mathrm{~nm}$. The growth process of [ $\left.\mathrm{Mn}_{\mathrm{x}} \mathrm{POMs}\right] \mathrm{n}$ was monitored by UV-vis spectroscopy. As shown in Figure 9 when comparing the absorption spectra of components $\mathrm{Mn}_{\mathrm{x}} \mathrm{POMs}$ in the composite film with components $\mathrm{Mn}_{\mathrm{x}} \mathrm{POMs}$ in the solution, it can be observed that the characteristic absorption peak of $\mathrm{Mn}_{\mathrm{x}} \mathrm{POMs}$ appears in the spectrum of each layer, indicating that $\mathrm{Mn}_{\mathrm{x}} \mathrm{POMs}$ has been assembled on the composite film. In addition, as shown in Figure S1c the absorbance value of $\mathrm{Mn}_{x} \mathrm{POMs}$ at the characteristic absorption peak is taken to draw the relationship with the number of composite film layers. It is found that there is a highly linear relationship between them, which proves that $\mathrm{Mn}_{\mathrm{x}} \mathrm{POMs}$ grows evenly on the composite film.

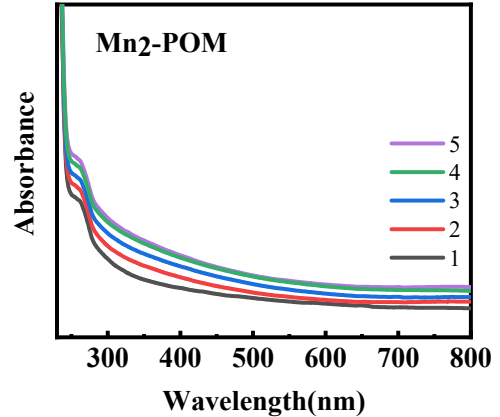

(a)

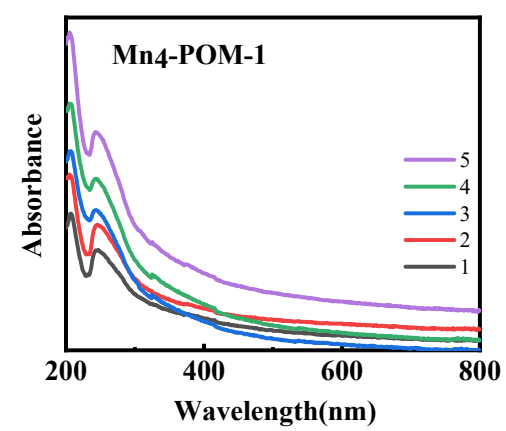

(b)

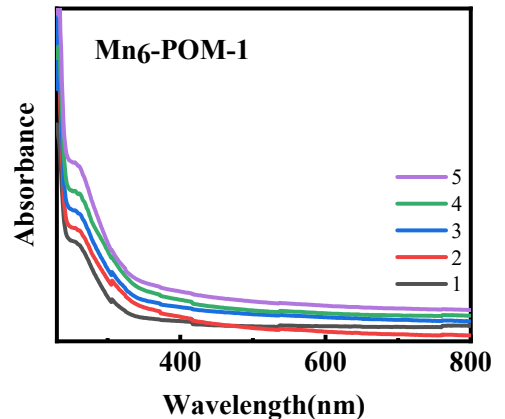

(c)

Figure 9. Cont. 


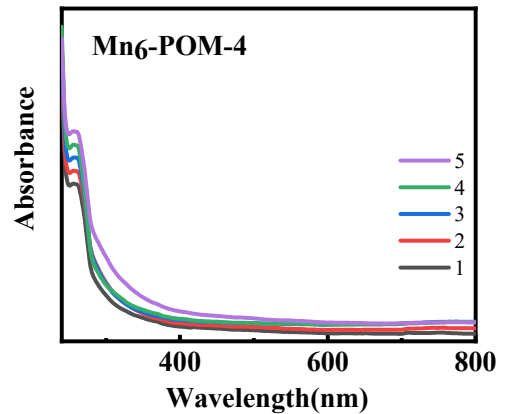

(d)

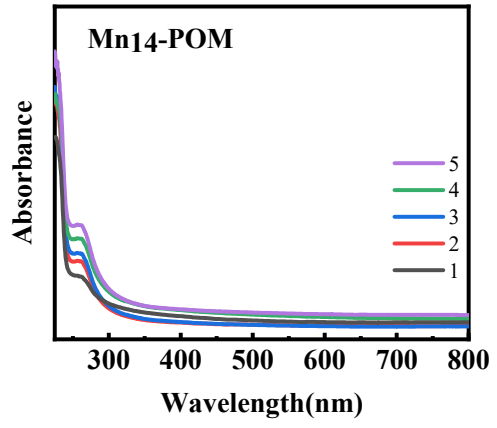

(e)

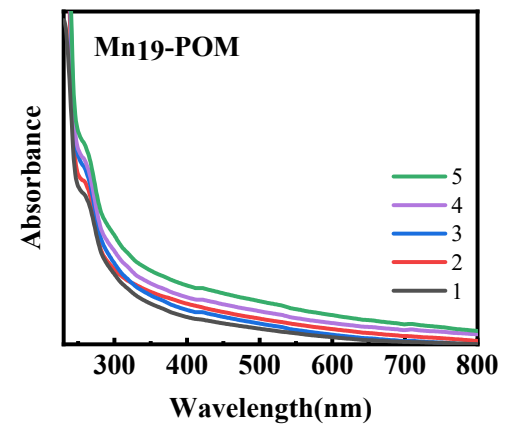

(f)

Figure 9. UV-vis spectra for (a) $\left[\mathrm{Mn}_{2}-\mathrm{POM}\right] \mathrm{n},(\mathbf{b})\left[\mathrm{Mn}_{4}-\mathrm{POM}\right] \mathrm{n},(\mathbf{c})\left[\mathrm{Mn}_{6}-\mathrm{POM}-1\right] \mathrm{n},(\mathbf{d})\left[\mathrm{Mn}_{6}-\mathrm{POM}-\right.$ $4] \mathrm{n},(\mathbf{e})\left[\mathrm{Mn}_{14}-\mathrm{POM}\right] \mathrm{n}$ and (f) $\left[\mathrm{Mn}_{19}-\mathrm{POM}\right] \mathrm{n}$ film on quartz slide $(n=1-5)$.

\subsection{Oxygen Evolution Reaction (OER) \\ 2.4.1. OER of $\mathrm{Mn}_{\mathrm{x}} \mathrm{POMs}$ Solution}

Firstly, we compared the catalytic water oxidation performance of MnxPOMs under the same solution concentration using cyclic voltammetry. From Figure 10, we can see that under the same potential conditions $(\mathrm{E}=1.4 \mathrm{~V})$, the order of the current density for $\mathrm{Mn}_{\mathrm{x}} \mathrm{POM}$ is as follows: $\mathrm{Mn}_{14}-\mathrm{POM}>\mathrm{Mn}_{19}-\mathrm{POM}>\mathrm{Mn}_{2}-\mathrm{POM}>\mathrm{Mn}_{4}-\mathrm{POM}>\mathrm{Mn}_{6}-\mathrm{POM}-4$ $>\mathrm{Mn}_{6}-\mathrm{POM}-1$, while at $\mathrm{E}=1.5 \mathrm{~V}$, the order is as follows: $\mathrm{Mn}_{14}-\mathrm{POM}>\mathrm{Mn}_{19}-\mathrm{POM}>$ $\mathrm{Mn}_{6}-\mathrm{POM}-4>\mathrm{Mn}_{2}-\mathrm{POM} \approx \mathrm{Mn}_{4}-\mathrm{POM}>\mathrm{Mn}_{6}-\mathrm{POM}-1$. See Table 2 for specific values.

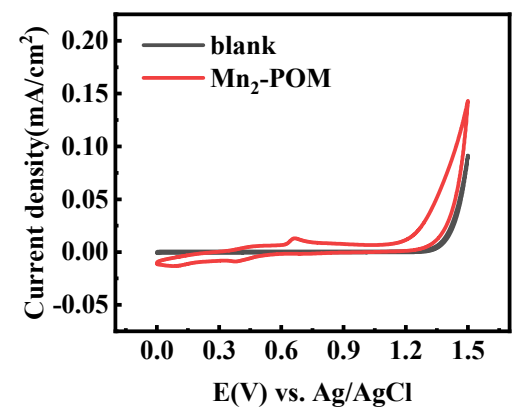

(a)

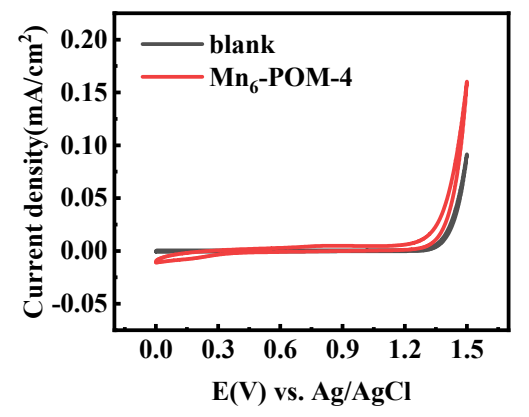

(d)

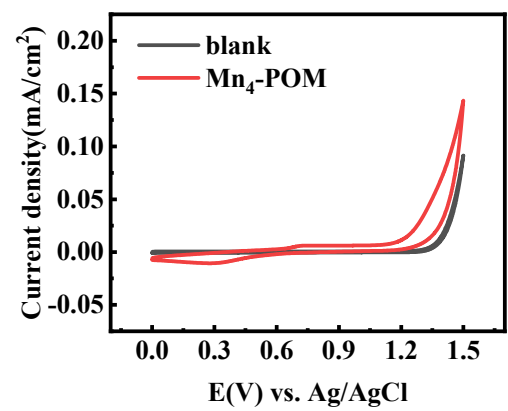

(b)

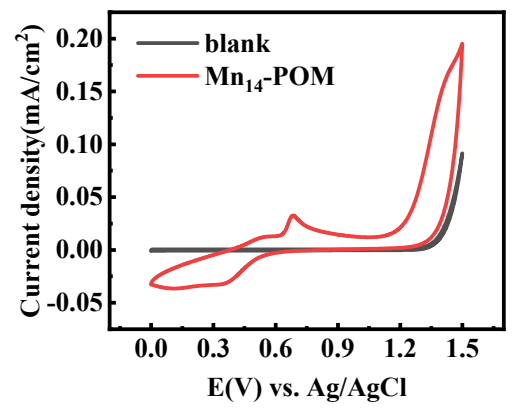

(e)

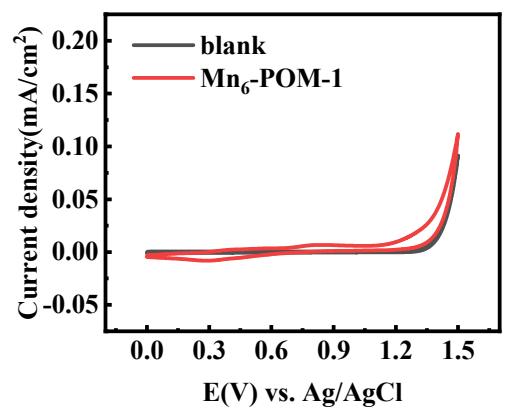

(c)

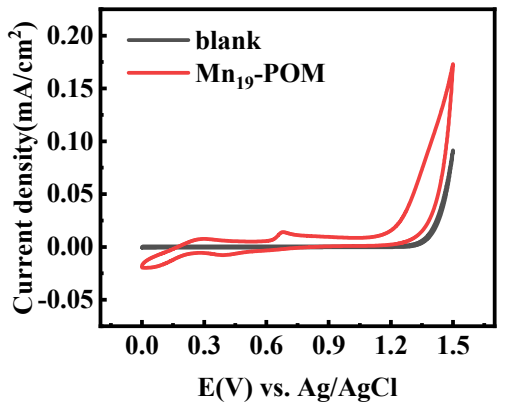

(f)

Figure 10. OER CV curves of $0.1 \mathrm{mM}$ (a) $\mathrm{Mn}_{2}-\mathrm{POM}$, (b) $\mathrm{Mn}_{4}-\mathrm{POM}$, (c) $\mathrm{Mn}_{6}-\mathrm{POM}-1$, (d) $\mathrm{Mn}_{6}-\mathrm{POM}-4$, (e) $\mathrm{Mn}_{14}$-POM and (f) $\mathrm{Mn}_{19}-\mathrm{POM}$ in $\mathrm{NaAc} / \mathrm{HAc}$ buffer $(0.5 \mathrm{M})$ at $\mathrm{pH}=7$. 
Table 2. Summary of oxygen evolution reaction current density.

\begin{tabular}{|c|c|c|}
\hline $\mathrm{Mn}_{\mathrm{x}} \mathrm{POMs}$ & $\begin{array}{l}\text { Current Density }\left(\mu \mathrm{A} \mathrm{cm}^{-2}\right) \\
\qquad \mathrm{E}=1.4 \mathrm{~V}\end{array}$ & $\begin{array}{l}\text { Current Density }\left(\mu \mathrm{A} \mathrm{cm}^{-2}\right) \\
\qquad \mathrm{E}=1.5 \mathrm{~V}\end{array}$ \\
\hline $\mathrm{Mn}_{2}-\mathrm{POM}$ & 75.73 & 143.2 \\
\hline $\mathrm{Mn}_{4}-\mathrm{POM}$ & 72.93 & 143.4 \\
\hline $\mathrm{Mn}_{6}$-POM-1 & 40.57 & 111.87 \\
\hline $\mathrm{Mn}_{6}-\mathrm{POM}-4$ & 46.69 & 160.2 \\
\hline $\mathrm{Mn}_{14}$-POM & 150.33 & 195.2 \\
\hline $\mathrm{Mn}_{19}-\mathrm{POM}$ & 102.6 & 173.07 \\
\hline
\end{tabular}

\subsubsection{OER of Assembled Thin Film Electrode}

In order to fix the $\mathrm{Mn}_{\mathrm{x}} \mathrm{POMs}$ on the electrode surface to reuse the catalyst, we chose the layer by layer assembly method to fabricate $\mathrm{Mn}_{\mathrm{x}} \mathrm{POMs}$ on the ITO electrode surface. See Section 3.3 for detailed operation steps. We assembled multilayer thin films and monitored the electrochemical behavior of thin film electrodes. It can be seen from Figure 11a that the redox peak current density of $\mathrm{Mn}_{x} \mathrm{POMs}$ on the electrode surface increases with the increase of the number of assembly layers. It can be seen from the inner graph that the oxidation peak current density has a linear relationship with the number of assembly layers. Combined with the regular changes of ultraviolet spectra in Figure $9 \mathrm{~b}, \mathrm{c}$, we can confirm the effectiveness of the layer by layer assembly method, and $\mathrm{Mn}_{\mathrm{x}} \mathrm{POMs}$ multilayer thin film electrodes were successfully prepared. At the same time, we monitored the catalytic water oxidation performance of the thin film electrode by Linear Scanning Voltammetry (LSV). It can be seen from Figure $11 \mathrm{~b}$ that the current density of the electrode catalytic water oxidation increases with the increase of the number of assembly layers. In order to facilitate comparison, we selected a representative $\left[\mathrm{Mn}_{x} \mathrm{POM}\right]_{3}$ for horizontal comparison, as shown in Figure 12.
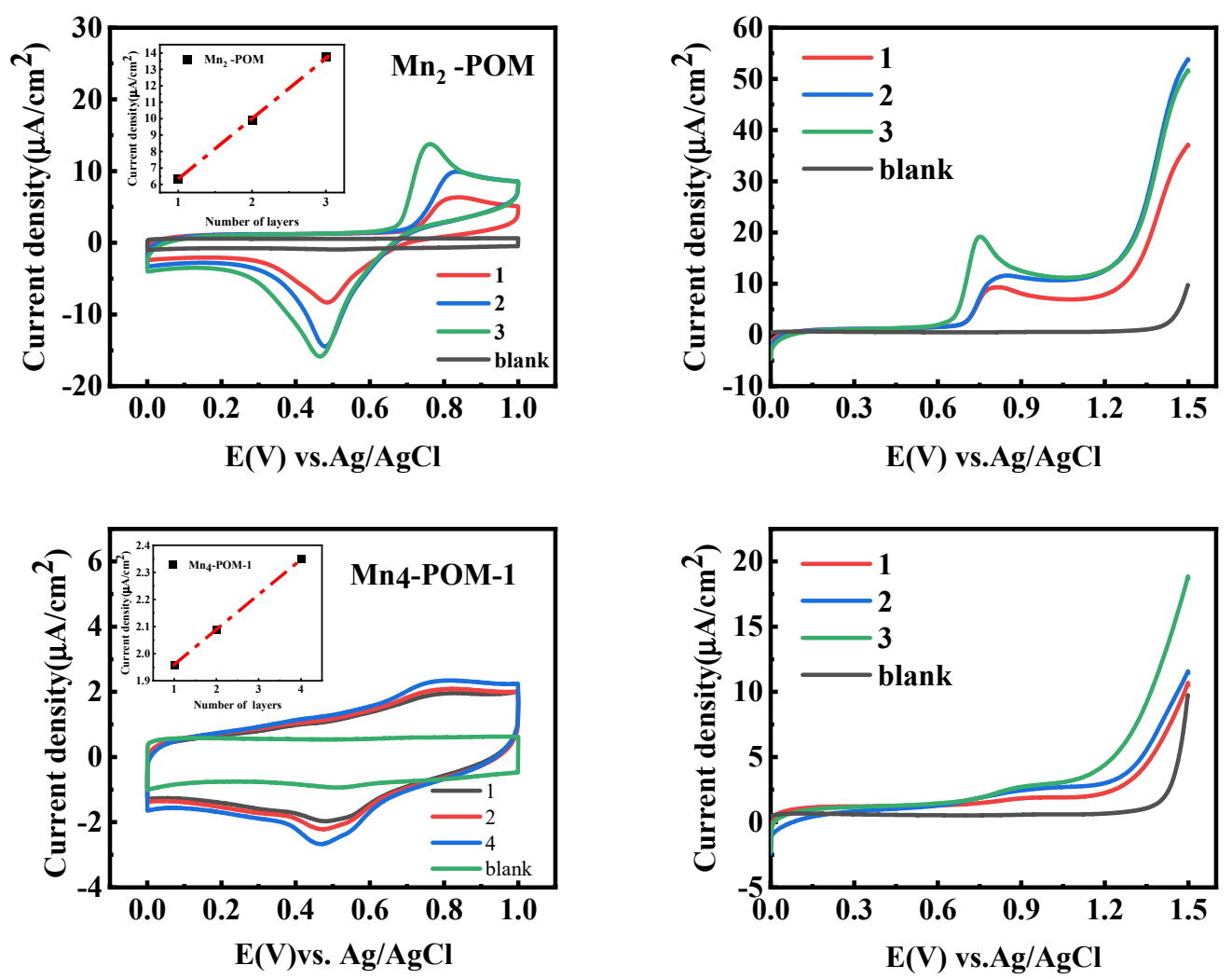

Figure 11. Cont. 

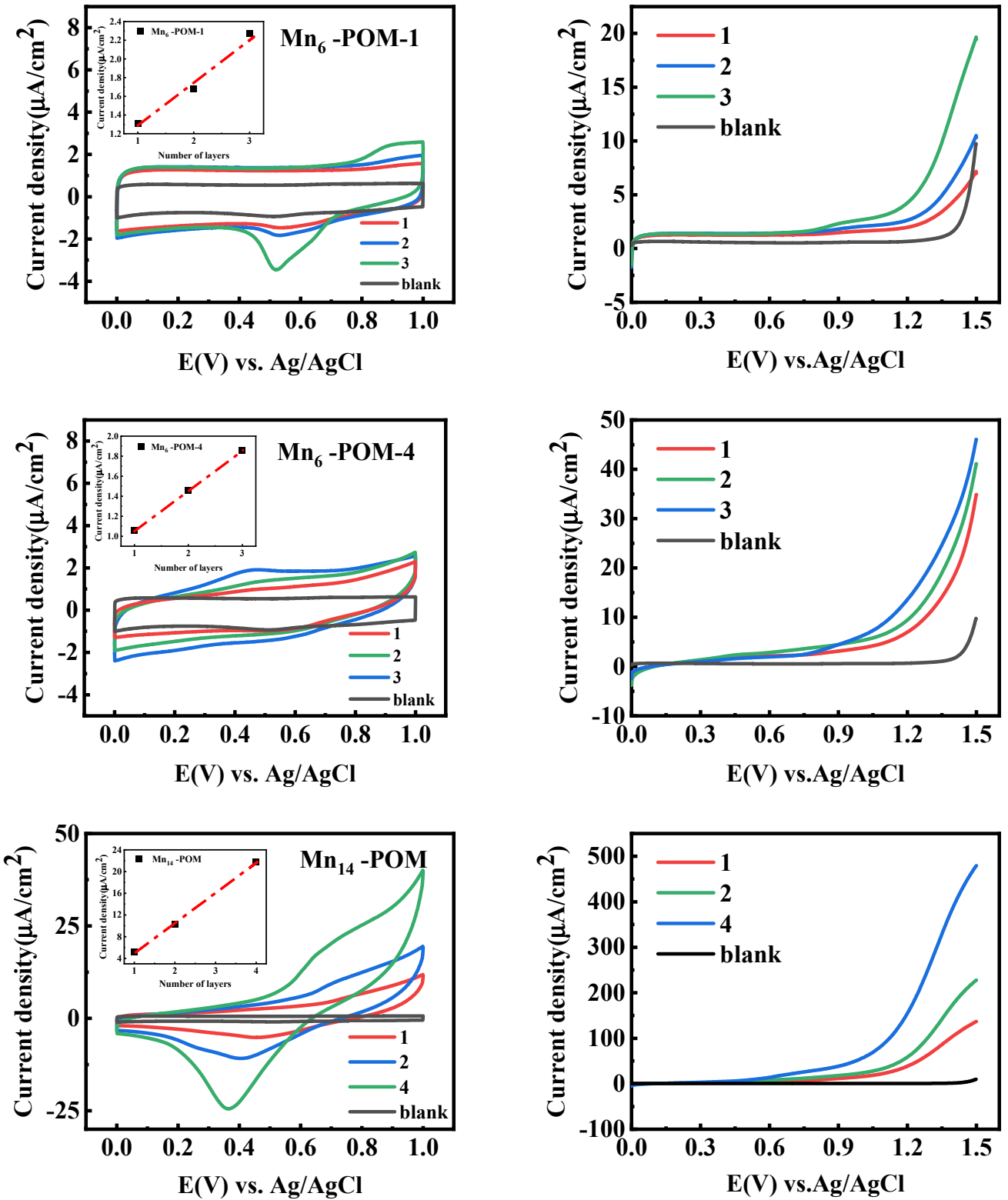

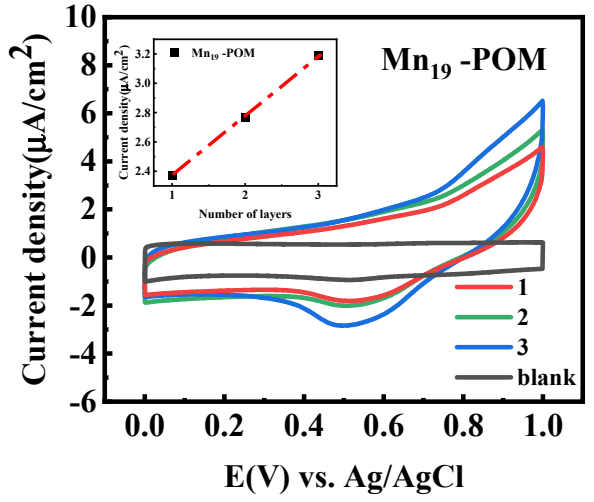

(a)

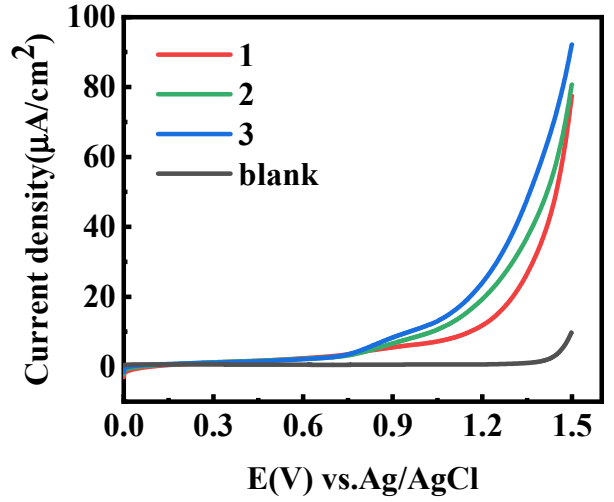

(b)

Figure 11. (a) $\mathrm{CV}$ curves of $\left[\mathrm{Mn}_{\mathrm{x}} \mathrm{POM}\right] \mathrm{n}$ film electrode in $\mathrm{NaAc} / \mathrm{HAc}$ buffer $(0.5 \mathrm{M})$ at $\mathrm{pH}=7$ (the inner graph is the relationship between the oxidation peak current of $\mathrm{Mn}^{\mathrm{II} / \mathrm{IV}}$ and the number of assembled layers.) (b) LSV curves of OER of [Mn $\left.n_{x} \mathrm{POM}\right] \mathrm{n}(n=1 / 2 / 3$ or 4$)$ film electrode in $\mathrm{NaAc} / \mathrm{HAc}$ buffer $(0.5 \mathrm{M})$ at $\mathrm{pH}=7$. 
As shown in Figure $12 \mathrm{a}$, we compared the OER performance of $\left[\mathrm{Mn}_{\mathrm{x}} \mathrm{POM}\right]_{3}$ thin film electrode. At $\mathrm{E}=1.4 \mathrm{~V}, \mathrm{Mn}_{14}$-POM has the highest current density $\left(250.97 \mu \mathrm{A} \mathrm{cm}^{-2}\right)$, followed by $\mathrm{Mn}_{19}$-POM. See Table 3 for specific values. We believe that the catalytic current of $\mathrm{Mn}_{\mathrm{x}} \mathrm{POM}$ may depend on the amount of $\mathrm{Mn}$ in $\mathrm{Mn}_{\mathrm{x}} \mathrm{POM}, \mathrm{Mn}$ valence and material structure. However, according to our experimental results, $\mathrm{Mn}_{14}$-POM current density is greater than $\mathrm{Mn}_{19}-\mathrm{POM}$, and $\mathrm{Mn}_{2}-\mathrm{POM}$ current density is greater than $\mathrm{Mn}_{6}-\mathrm{POM}$. The amount of $\mathrm{Mn}$ in $\mathrm{Mn}_{\mathrm{x}} \mathrm{POM}$ is not a decisive factor. We believe that among the six manganese containing POMs, $\mathrm{Mn}_{14}$-POM has the largest current density, the smallest catalytic peak starting potential $(0.92 \mathrm{~V})$ and the highest catalytic performance, which should be attributed to its $\mathrm{Mn}-\mathrm{O}$ cluster cubic structure and its manganese in a higher oxidation state. The Mn-O cluster cubic structure is similar to that of the PSII active center, $\left[\mathrm{Mn}_{4} \mathrm{CaO}_{5}\right]$. In fact, there are two trivalent $\mathrm{Mn}$ and two tetravalent $\mathrm{Mn}$ in $\left[\mathrm{Mn}_{4} \mathrm{CaO}_{5}\right]$, and $\mathrm{Mn}_{14}-\mathrm{POM}$ is similar to it. Among them, the view of Mn-O cluster cubic structure is also confirmed in the comparison of two $\mathrm{Mn}_{6}$-POM with the same number and the same valence of $\mathrm{Mn}$. The current density of $\mathrm{Mn}_{6}$-POM-4 (29.73 $\left.\mu \mathrm{A} \mathrm{cm}{ }^{-2}\right)$ with Mn-O cluster cubic structure is more than twice that of $\mathrm{Mn}_{6}$-POM $\left(13.22 \mu \mathrm{A} \mathrm{cm}{ }^{-2}\right)$ at $1.4 \mathrm{~V}$ potential, and the peak onset potential is $1.07 \mathrm{~V}$, which is $0.15 \mathrm{~V}$ ahead of $\mathrm{Mn}_{6}-\mathrm{POM}-1$.

In Table 4, some study reports regarding the electrocatalytic activity of manganese containing POMs for water decomposition are listed for comparison. They all adopt the layer by layer assembly method, which is comparable. In contrast, $\mathrm{Mn}_{14}-\mathrm{POM}$ with $\mathrm{Mn}-\mathrm{O}$ cubic structure shows better catalytic performance.
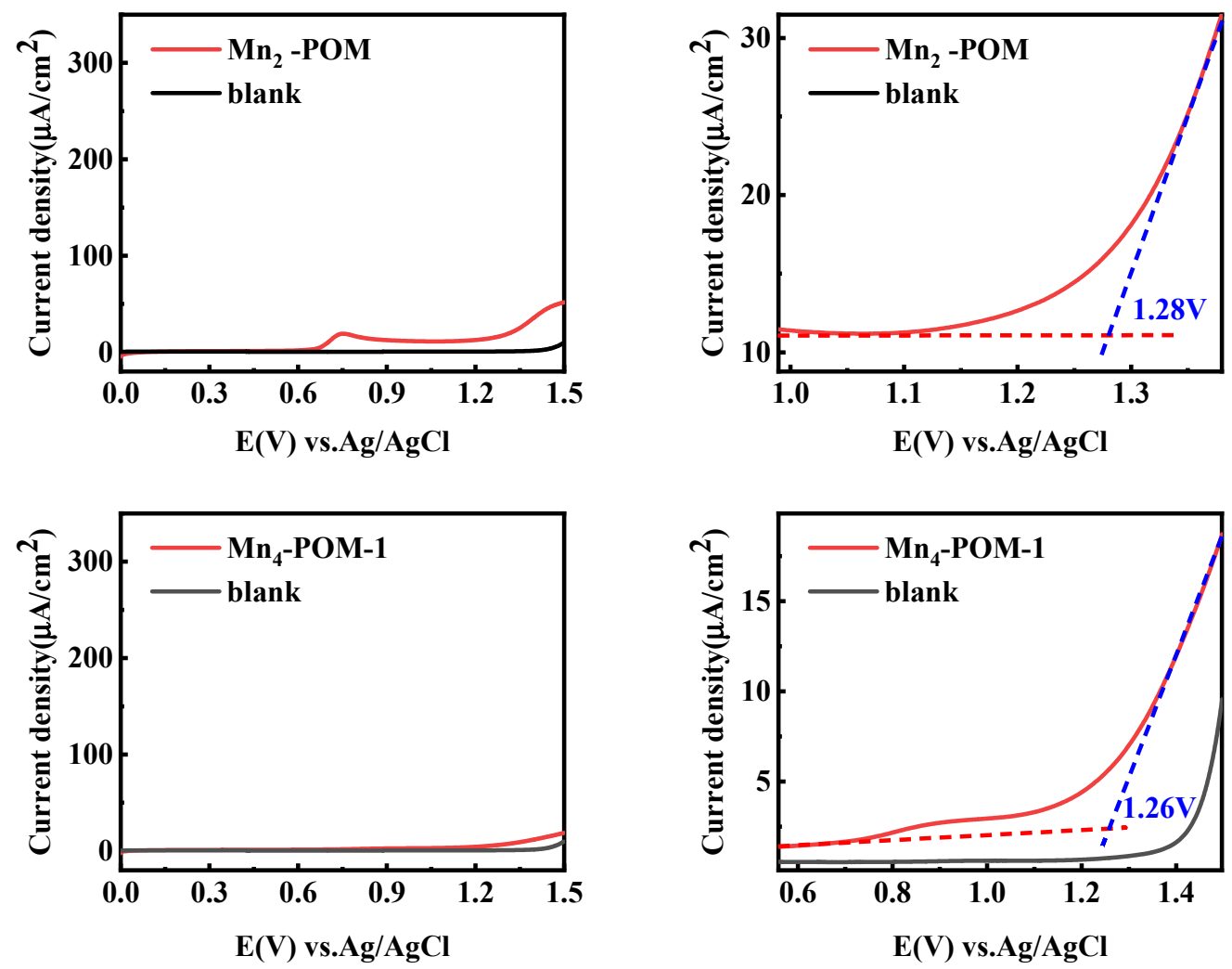

Figure 12. Cont. 

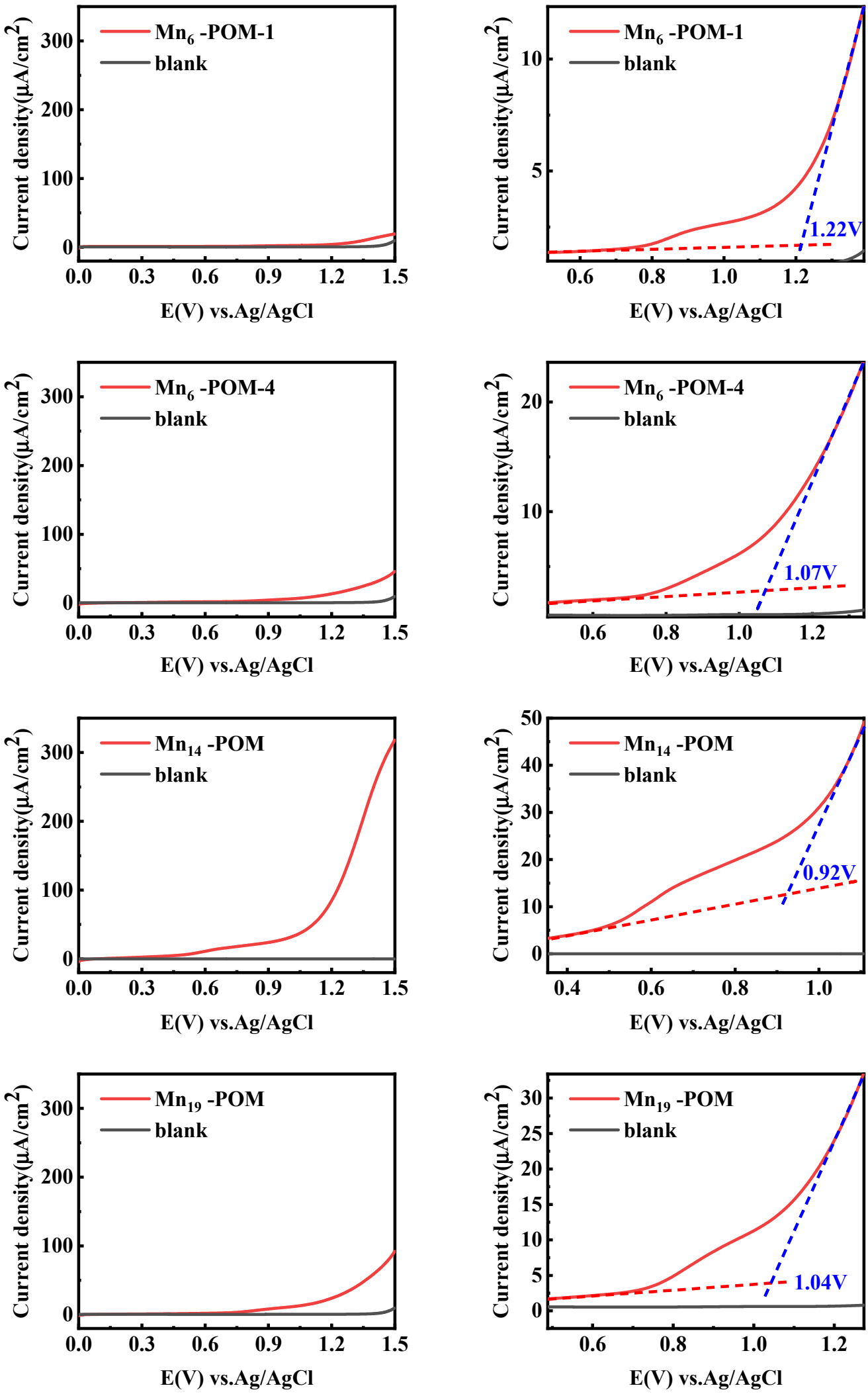

(a)

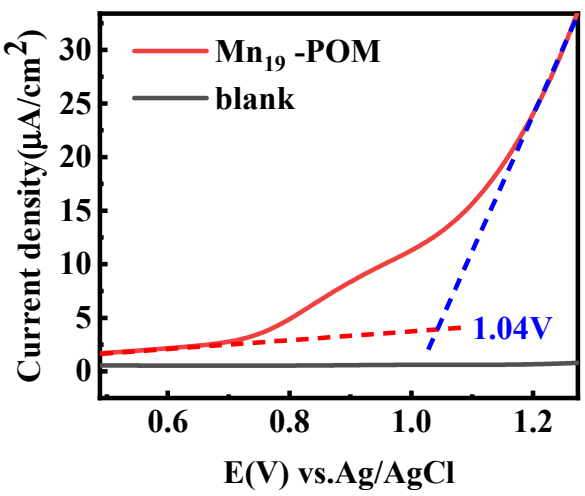

(b)

Figure 12. (a) LSV curves of OER of $\left[\mathrm{Mn}_{\mathrm{x}} \mathrm{POM}\right]_{3}$ film electrode in NaAc/HAc buffer $(0.5 \mathrm{M})$ at $\mathrm{pH}=7$; (b) The locally enlarged graph of LSV curves of OER of $\left[\mathrm{Mn}_{\mathrm{x}} \mathrm{POM}\right]_{3}$ film electrode. 
Table 3. Summary of initial potential of oxygen evolution reaction.

\begin{tabular}{|c|c|c|}
\hline $\mathrm{Mn}_{\mathrm{x}}$ POMs & Current Density $\left(\mu \mathrm{A} \mathrm{cm}^{-2}\right) \mathrm{E}=1.4 \mathrm{~V}$ & $\mathrm{E}(\mathrm{V})_{\text {on }}$ \\
\hline $\mathrm{Mn}_{2}-\mathrm{POM}$ & 36.31 & 1.28 \\
\hline $\mathrm{Mn}_{4}-\mathrm{POM}$ & 11.98 & 1.26 \\
\hline $\mathrm{Mn}_{6}-\mathrm{POM}-1$ & 13.22 & 1.22 \\
\hline $\mathrm{Mn}_{6}-\mathrm{POM}-4$ & 29.73 & 1.07 \\
\hline $\mathrm{Mn}_{14}$-POM & 250.97 & 0.92 \\
\hline $\mathrm{Mn}_{19}-\mathrm{POM}$ & 59.51 & 1.04 \\
\hline
\end{tabular}

Table 4. Comparison of electrocatalytic water oxidation properties of different manganese containing POM.

\begin{tabular}{|c|c|c|}
\hline $\mathrm{Mn}_{\mathrm{x}}$ POMs & Current Density $\left(\mu \mathrm{A} \mathrm{cm}^{-2}\right) \mathrm{E}=1.5 \mathrm{~V}$ & Ref. \\
\hline Mn16-Cs ${ }^{c}$ & ca. 244.4 & [9] \\
\hline $\mathrm{NaK}-\mathrm{Mn} 4^{\mathrm{b}}$ & ca. 83 & [10] \\
\hline $\mathrm{Mn}_{14}-\mathrm{POM}^{\mathrm{a}}$ & 479.2 & this work \\
\hline
\end{tabular}

a Conditions: ITO $\left(\mathrm{S}=1.5 \mathrm{~cm}^{2}\right)$, LBL $(n=4), 0.5 \mathrm{M} \mathrm{NaAc}+\mathrm{HAc}(\mathrm{pH} 7)$, Scan rate: $50 \mathrm{mV} / \mathrm{s}$; ${ }^{\mathrm{b}}$ Conditions: ITO $\left(S=3 \mathrm{~cm}^{2}\right)$, LBL $(n=4), 1 \mathrm{M} \mathrm{NaAc}+\mathrm{HAc}(\mathrm{pH} 7)$, Scan rate: $50 \mathrm{mV} / \mathrm{s} ;{ }^{\mathrm{c}}$ Conditions: ITO $\left(\mathrm{S}=1.35 \mathrm{~cm}^{2}\right)$, LBL $(n=4), 0.5 \mathrm{M} \mathrm{NaAc}+\mathrm{HAc}(\mathrm{pH} 7)$, Scan rate: $50 \mathrm{mV} / \mathrm{s}$.

It can be seen from Table 4 that $\mathrm{Mn}_{14}$-POM in this paper has better OER catalytic properties compared with other manganese containing POMs tested by the same method. At the same time, in order to understand the practical prospect of our materials, we have compared them with precious metal commercial reference materials in Table 5. The experimental environment is neutral. It is found that there are still some gaps that can be improved.

Table 5. Comparison of electrocatalytic water oxidation properties of noble catalysts with $\mathrm{Mn}_{14}-\mathrm{POM}$.

\begin{tabular}{|c|c|c|c|}
\hline Catalysts & $\mathrm{E}_{\text {onset }}(\mathrm{V})$ vs. $\mathrm{Ag} / \mathrm{AgCl}$ & $\mathrm{E}(\mathrm{V})$ (Current Density $=400 \mu \mathrm{A} \mathrm{cm}^{-2}$ ) & Ref. \\
\hline $\mathrm{Pt} b$ & 0.89 & 1.02 & [22] \\
\hline $\mathrm{IrO} 2^{\mathrm{b}}$ & 0.89 & 0.99 & [22] \\
\hline $\mathrm{Mn}_{14}-\mathrm{POM}^{\mathrm{a}}$ & 0.92 & 1.41 & this work \\
\hline
\end{tabular}

a Conditions: ITO $\left(\mathrm{S}=1.5 \mathrm{~cm}^{2}\right)$, LBL $(n=4), 0.5 \mathrm{M} \mathrm{NaAc}+\mathrm{HAc}(\mathrm{pH} 7)$, Scan rate: $50 \mathrm{mV} / \mathrm{s}^{\text {; }}{ }^{\mathrm{b}}$ Conditions: $0.1 \mathrm{M}$ PBS $(\mathrm{pH}=7)$, Scan rate: $5 \mathrm{mV} / \mathrm{s}$.

The durability and stability of materials have also been studied., taking $\mathrm{Mn}_{14} \mathrm{POM}$ as an example. As shown in Figure 13, we compared the electrocatalytic oxidation performance of a thin film electrode before and after standing for 48 days. We can observe that after standing for 48 days, the peak potential of electrocatalytic oxidation of the thin film electrode moves slightly forward, but the catalytic current density at $1.5 \mathrm{~V}$ potential does not change significantly, it shows that the catalytic components in the thin film electrode can exist stably on the electrode surface for a long time. Then, the electrode was electrolyzed at a constant potential for $1200 \mathrm{~s}$, and the LSV test was carried out again. It was found that the peak potential of electrocatalytic oxidation of the thin film electrode moved slightly forward, and the catalytic current density decreased by $22 \%$, which was caused by the partial falling off of the main catalytic components during the test. The stability of other $\mathrm{Mn}_{\mathrm{x}} \mathrm{POMs}$ materials can be found in the supporting information. 


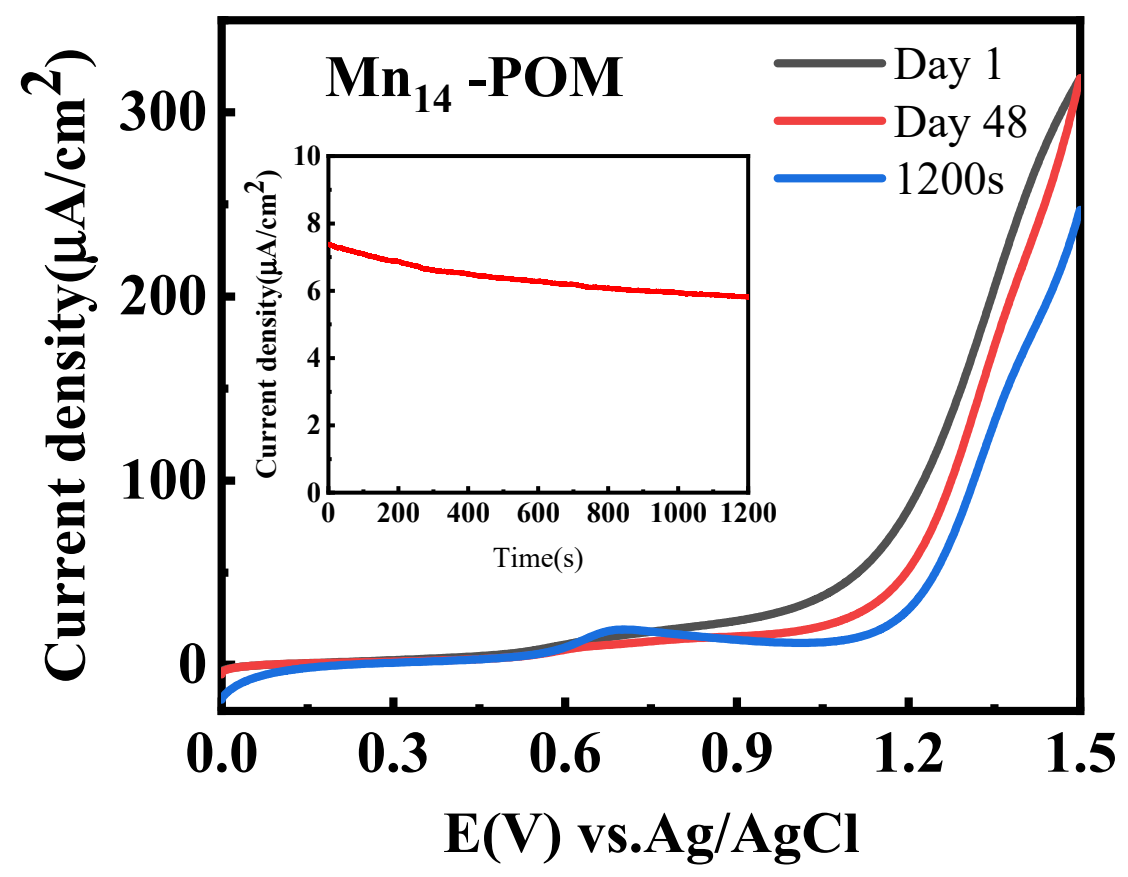

Figure 13. LSV curves of OER of $\left[\mathrm{Mn}_{14} \mathrm{POM}\right]_{3}$ film electrode in NaAc/HAc buffer $(0.5 \mathrm{M})$ at $\mathrm{pH}=7$, the black line is the initial, the red line is after 48 days, and the blue line is after potentiostatic electrolysis. The inset shows the current time curve of $\left[\mathrm{Mn}_{14} \mathrm{POM}\right]_{3}$ film electrode in $\mathrm{NaAc} / \mathrm{HAc}$ buffer $(0.5 \mathrm{M})$ at $\mathrm{pH}=7$.

\section{Materials and Methods}

\subsection{Materials and Apparatus}

\subsubsection{Materials}

Poly (diallyldimethylammonium chloride) (PDDA) (Mw = 10,000-20,000) and poly (4-styrene sulfonic acid) sodium salt (PSS) were obtained from Sigma Aldrich (Merck $\mathrm{KGaA}$, Darmstadt, Germany). Sodium tungstate $\left(\mathrm{Na}_{2} \mathrm{WO}_{4} \cdot 2 \mathrm{H}_{2} \mathrm{O}\right)$, sodium metasilicate $\left(\mathrm{Na}_{2} \mathrm{SiO}_{3} \cdot 5 \mathrm{H}_{2} \mathrm{O}\right)$, Sodium phosphate $\left(\mathrm{Na}_{3} \mathrm{PO}_{4}\right)$, disodium hydrogen phosphate $\left(\mathrm{Na}_{2} \mathrm{HPO}_{4}\right)$, sodium hydroxide $(\mathrm{NaOH})$, manganese chloride $\left(\mathrm{MnCl}_{2}\right)$, manganous acetate tetrahydrate $\left(\mathrm{Mn}(\mathrm{OAc})_{2} \cdot 2 \mathrm{H}_{2} \mathrm{O}\right)$ potassium carbonate $\left(\mathrm{K}_{2} \mathrm{CO}_{3}\right)$, potassium persulfate $\left(\mathrm{K}_{2} \mathrm{~S}_{2} \mathrm{O}_{8}\right)$, hydrochloric acid $(\mathrm{HCl})$, potassium chloride $(\mathrm{KCl})$, germanium dioxide $\left(\mathrm{GeO}_{2}\right)$, imidazole and ethanol were analytical grade and used as received. Water was purified by Millipore Milli-Q (Merck Millipore, Darmstadt, Germany).

\subsubsection{Apparatus}

A PHS-25B digital acidimeter (Yuechen, Shanghai, China) determined the $\mathrm{pH}$ value. The infrared spectra (IR) were measured on a spectrometer (Bruker Vertex 80V, Bruker, Karlsruhe, Germany). Absorption measurements (UV-vis) were completed with UV-2700 UV-Visible spectrophotometer (Shimadzu, Kyoto, Japan). The cyclic voltammetry curve (CV) and the linear sweep voltammetry curve (LSV) were recorded using CHI660e electrochemical workstation (Shanghai Chenhua Instrument Co., Ltd., Shanghai, China). X-ray photoelectron spectroscopy (XPS) analysis was obtained by Escalab 250 X-ray photoelectron spectrometer (Thermo Fisher Scientific, Waltham, MS, USA).

\subsection{Preparation of Polynuclear Manganese Containing Polyoxometalates}

$\mathrm{Mn}_{\mathrm{x}} \mathrm{POMs}$ were synthesized according to the literature [13-18]. Please see supplementary information for details. 


\subsection{LBL Assembled Composite Film Modified Electrode}

Before assembly, the substrate (ITO electrode) needed to be cleaned according to the literature [23]. The ITO was immersed in $1 \mathrm{M} \mathrm{NaOH}: \mathrm{CH}_{3} \mathrm{CH}_{2} \mathrm{OH}(\mathrm{V}: \mathrm{V}=1: 1)$ mixed solution, ultrasonically for $20 \mathrm{~min}$, then cleaned with water, and then dried with nitrogen for standby. Then, the composite film was assembled on the clean substrate by the LbL assembly method. First, the substrate was immersed in the positively charged PDDA (5\%) solution and left to stand for $20 \mathrm{~min}$. Second, the substrate was immersed in the negatively charged PSS solution for $20 \mathrm{~min}$. Third, the substrate was immersed in the PDDA (5\%) aqueous solution for $20 \mathrm{~min}$. Fourth, the substrate was immersed in $0.5 \mathrm{mM} \mathrm{Mn}{ }_{\mathrm{x}} \mathrm{POMs}$ solution with a negative charge for $20 \mathrm{~min}$. After each assembly, the substrate was washed with water 3-5 times to remove the physical adsorption substances, and then dried with nitrogen flow. After the above steps, the monolayer [PDDA/PSS/PDDA $/ \mathrm{Mn}_{\mathrm{x}} \mathrm{POM}$ ] composite films were prepared. Different layers of [PDDA/PSS/PDDA/ $\mathrm{Mn}_{\mathrm{x}} \mathrm{POM}$ ]n-ITO $(n=1-4)$ composite film modified electrodes were prepared by repeating steps 3 and 4 .

\subsection{UV-Vis Absorption Spectra}

The fabrication process of the samples is the same as that of the LBL assembling the multilayer film modified electrode in Section 3.3. The only difference is that ITO is replaced by a quartz slide. Firstly, the quartz glass was cleaned according to the literature method [24] (different from ITO), and then assembled according to the film assembly steps, monitoring the assembly process of composite films by UV-vis absorption spectrum.

\subsection{Electrochemical Test}

A series of experiments were performed to study the PEC catalytic activity for water oxidation, ITO/PDDA/PSS/[PDDA/ $\left.\mathrm{Mn}_{\mathrm{x}} \mathrm{POM}\right] \mathrm{n}$ was used as the working electrode, using $\mathrm{Ag} / \mathrm{AgCl}$ as a reference electrode, and a platinum wire as a counter electrode. The buffer solution was obtained from $0.5 \mathrm{M} \mathrm{pH} 7 \mathrm{CH}_{3} \mathrm{COONa}(\mathrm{NaAc})$ solutions adjusted by $\mathrm{CH}_{3} \mathrm{COOH}$ (HAc). Before the electrochemical experiments, the oxygen in the electrolyte was removed by purging high-purity nitrogen. All the electrochemical measurements were performed on an electrochemical workstation (CHI 611E, CH Instruments Co., Ltd., Shanghai, China) at room temperature.

\section{Conclusions}

Via appropriate choice, six Mn-containing POMs, with different structures, composition, $\mathrm{Mn}-\mathrm{O}$ clusters and oxidation state of $\mathrm{Mn}$, were prepared and their electrocatalytic water oxidation performance was investigated under the same experiment conditions in solution and composite film. The fabrication of the composite films was characterized by UV-vis spectra and CVs, confirming that the $\mathrm{Mn}_{\mathrm{x}} \mathrm{POMs}$ have been fabricated on the composite films and their electrochemical properties have been maintained very well in the composite films. Through a series of controlled experiments, the following rules were obtained: the amount and the oxidation state of $\mathrm{Mn}$ ions in $\mathrm{Mn}_{\mathrm{x}} \mathrm{POM}$ affect the electrocatalytic water oxidation performance; at the same time, the structure of $\mathrm{Mn}$-O clusters in $\mathrm{Mn}_{x} \mathrm{POM}$ also affects the electrocatalytic water oxidation performance. After the comparison, it is found that among the six $\mathrm{Mn}_{\mathrm{x}} \mathrm{POMs}, \mathrm{Mn}_{14}$-POM displays the highest electrocatalytic performance towards water oxidation. Such observation indicates the oxidation state of $\mathrm{Mn}$ and the structure of $\mathrm{Mn}-\mathrm{O}$ cluster cubic structure are very important factors impacting electrocatalytic performance for the water oxidation as the oxidation state of $\mathrm{Mn}$ and the structure of $\mathrm{Mn}-\mathrm{O}$ cluster in $\mathrm{Mn}_{14}-\mathrm{POM}$ are the same as that in the photocatalytic active center (PSII). Therefore, Therefore, this study provides a reference for further screening water oxidation catalysts with high performance. 


\begin{abstract}
Supplementary Materials: The following supporting information can be downloaded at https: / / www.mdpi.com/article/10.3390/catal12020160/s1, Figure S1: (a) UV-vis absorption spectra of MnxPOMs $(5 \mu \mathrm{M})$ in the aqueous solutions; (b) UV-vis spectra for the [MnxPOMs]n film on quartz slide; (c) relationship of the absorbance value and layer number at $\lambda=243 \sim 257 \mathrm{~nm}$; Figure S2: LSV curves of OER of [Mn2-POM]1 and [MnxPOM]3 film electrode in NaAc/HAc buffer $(0.5 \mathrm{M})$ at $\mathrm{pH}=7$, initial, after 48 days, and after potentiostatic electrolysis;; Table S1: Summary of the radio of current density and the difference of initial potential of OER;; Figure S3: XPS spectra of [Mn2-POM]5(a), C1s(b), Mn2p(c), Si2p(d), W4f(e) and O1s(f); Figure S4: XPS spectra of [Mn4-POM]5(a), C1s(b), Mn2p(c), P2p(d), W4f(e) and O1s(f); Figure S5: XPS spectra of [Mn6-POM-1]5(a), C1s(b), Mn2p(c), Ge3p(d), Ge3d(e), W4f(f) and O1s(g); Figure S6: XPS spectra of [Mn6-POM-4]5(a), C1s(b), Mn2p(c), Si2p(d), W4f(e) and O1s(f); Figure S7: XPS spectra of [Mn14-POM]5(a), C1s(b), Mn2p(c), W4f(d) and O1s(e); Figure S8: XPS spectra of [Mn19-POM]5(a), C1s(b), Mn2p(c), Si2p(d), W4f(e) and O1s(f).
\end{abstract}

Author Contributions: Conceptualization, Y.W. and L.B.; methodology, Y.W.; software, Y.W.; validation, Y.W., J.P. and X.Y.; formal analysis, Y.W.; investigation, Y.W.; data curation, Y.W.; writingoriginal draft preparation, Y.W.; writing-review and editing, L.B.; supervision, L.B. All authors have read and agreed to the published version of the manuscript.

Funding: This research received no external funding.

Data Availability Statement: The data presented in this study are available on request from the corresponding author. The data are not publicly available due to the need of follow-up research.

Acknowledgments: Thank the co-author for their help in writing this article. Thank the reviewers for their comments and valuable opinions, and the editors for their help in publishing this article.

Conflicts of Interest: The authors declare no conflict of interest.

\title{
References
}

1. Pope, M.T.; Müller, A. Polyoxometalate Chemistry: An Old Field with New Dimensions in Several Disciplines. Angew. Chem. Int. Ed. 1991, 30, 34-48. [CrossRef]

2. Orlandi, M.; Argazzi, R.; Sartorel, A.; Carraro, M.; Scorrano, G.; Bonchio, M.; Scandola, F. Ruthenium polyoxometalate water splitting catalyst: Very fast hole scavenging from photogenerated oxidants. Chem. Commun. 2010, 46, 3152-3154. [CrossRef] [PubMed]

3. Patel, A.; Sadasivan, R. Modified Mn substituted POMs: Synthetic strategies, structural diversity to applications. Prog. Mater. Sci. 2021, 118, 100759. [CrossRef]

4. Ensafi, A.A.; Heydari-Soureshjani, E.; Rezaei, B. Nanostructure polyoxometalates containing Co, Ni, and Cu as powerful and stable catalysts for hydrogen evolution reaction in acidic and alkaline solutions. Int. J. Hydrog. Energy 2017, 42, 5026-5034. [CrossRef]

5. Liu, Z.-J.; Wang, X.-L.; Qin, C.; Zhang, Z.-M.; Li, Y.-G.; Chen, W.-L.; Wang, E.-B. Polyoxometalate-assisted synthesis of transitionmetal cubane clusters as artificial mimics of the oxygen-evolving center of photosystem II. Co-ord. Chem. Rev. 2016, 313, 94-110. [CrossRef]

6. Al-Oweini, R.; Bassil, B.S.; Friedl, J.; Kottisch, V.; Ibrahim, M.; Asano, M.; Keita, B.; Novitchi, G.; Lan, Y.; Powell, A.; et al. Synthesis and Characterization of Multinuclear Manganese-Containing Tungstosilicates. Inorg. Chem. 2014, 53, 5663-5673. [CrossRef]

7. Das, S.; Misra, A.; Roy, S. Enhancement of photochemical heterogeneous water oxidation by a manganese based soft oxometalate immobilized on a graphene oxide matrix. New J. Chem. 2016, 40, 994-1003. [CrossRef]

8. Yu, L.; Ding, Y.; Zheng, M. Polyoxometalate-based manganese clusters as catalysts for efficient photocatalytic and electrochemical water oxidation. Appl. Catal. B Environ. 2017, 209, 45-52. [CrossRef]

9. Du, Y.; Yu, T.; Fu, Z.; Bi, L. A multilayer assembly of two mixed-valence Mn16-containing polyanions and study of their electrocatalytic activities towards water oxidation. Dalton Trans. 2018, 47, 7282-7289. [CrossRef]

10. Zhou, Q.; Du, Y.; Qu, Z.; Bi, L. Facile multilayer assemble of a mixed-valence Mn4-containing silicotungstate and its electrochemical study with $\mathrm{Co}_{3} \mathrm{O}_{4}$ as co-catalyst for photoelectrocatalytic water oxidation. J. Electroanal. Chem. 2021, 894, 115339. [CrossRef]

11. Al-Oweini, R.; Sartorel, A.; Bassil, B.; Natali, M.; Berardi, S.; Scandola, F.; Kortz, U.; Bonchio, M. Photocatalytic Water Oxidation by a Mixed-Valent $\mathrm{Mn}_{3}^{\mathrm{III}} \mathrm{Mn}^{\mathrm{IV}} \mathrm{O}_{3}$ Manganese Oxo Core that Mimics the Natural Oxygen-Evolving Center. Angew. Chem. Int. Ed. 2014, 53, 11182-11185. [CrossRef] [PubMed]

12. Schwarz, B.; Forster, J.; Goetz, M.K.; Yücel, D.; Berger, C.; Jacob, T.; Streb, C. Visible-Light-Driven Water Oxidation by a Molecular Manganese Vanadium Oxide Cluster. Angew. Chem. Int. Ed. 2016, 55, 6329-6333. [CrossRef] [PubMed]

13. Car, P.-E.; Spingler, B.; Weyeneth, S.; Patscheider, J.; Patzke, G. All-inorganic 1D chain-based architecture of a novel dimanganesesubstituted Keggin polyoxotungstate. Polyhedron 2013, 52, 151-158. [CrossRef] 
14. Zhang, X.-Y.; Jameson, G.B.; O'Connor, C.J.; Pope, M.T. High-valent manganese in polyoxotungstates-II. Oxidation of the tetramanganese heteropolyanion $\left[\mathrm{Mn}_{4}\left(\mathrm{H}_{2} \mathrm{O}\right)_{2}\left(\mathrm{PW}_{9} \mathrm{O}_{34}\right)_{2}\right]^{10-}$. Polyhedron 1996, 15, 917-922. [CrossRef]

15. Jiang, N.; Li, F.; Xu, L.; Li, Y.; Li, J. New assembly of transition metal complexes based on [GeW9O34]10- building blocks: Syntheses, crystal structures and magnetic properties. Inorg. Chem. Commun. 2010, 13, 372-375. [CrossRef]

16. Mitchell, S.G.; Molina, P.I.; Khanra, S.; Miras, H.N.; Prescimone, A.; Cooper, G.J.T.; Winter, R.S.; Brechin, E.K.; Long, D.-L.; Cogdell, R.J.; et al. A Mixed-Valence Manganese Cubane Trapped by Inequivalent Trilacunary Polyoxometalate Ligands. Angew. Chem. Int. Ed. 2011, 50, 9154-9157. [CrossRef]

17. Fang, X.; Luban, M. $\left\{\mathrm{Mn}_{14} \mathrm{~W}_{48}\right\}$ aggregate: The perspective of isopolyanions as ligands. Chem. Commun. 2011, 47, 3066-3068 [CrossRef]

18. Bassil, B.S.; Ibrahim, M.; Al-Oweini, R.; Asano, M.; Wang, Z.; van Tol, J.; Dalal, N.S.; Choi, K.-Y.; Ngo, B.R.; Keita, B.; et al. A Planar $\left\{\mathrm{Mn}_{19}(\mathrm{OH})_{12}\right\}^{26+}$ Unit Incorporated in a 60-Tungsto-6-Silicate Polyanion. Angew. Chem.-Int. Ed. 2011, 50, 5961-5964. [CrossRef]

19. Wu, Y.; Yu, X.; Fu, Z.; Pei, J.; Bi, L. Fabrication of Six Manganese Containing Polyoxometalate Modified Graphite $\mathrm{C}_{3} \mathrm{~N}_{4} \mathrm{Nanosheets}$ Catalysts Used to Catalyze Water Decomposition. Catalysts 2021, 11, 856. [CrossRef]

20. Santos, I.C.; Gamelas, J.A.; Duarte, T.A.; Simoes, M.M.; Neves, M.G.P.; Cavaleiro, J.A.; Cavaleiro, A.M. Catalytic homogeneous oxidation of monoterpenes and cyclooctene with hydrogen peroxide in the presence of sandwich-type tungstophosphates $\left[\mathrm{M}_{4}\left(\mathrm{H}_{2} \mathrm{O}\right)_{2}\left(\mathrm{PW}_{9} \mathrm{O}_{34}\right)_{2}\right]^{\mathrm{n}-}, \mathrm{M}=\mathrm{CoII}, \mathrm{MnII}$ and FeIII. J. Mol. Catal. A Chem. 2017, 426, 593-599. [CrossRef]

21. Zou, G.; Zhong, W.; Mao, L.; Xu, Q.; Xiao, J.; Yin, D.; Xiao, Z.; Kirk, S.R.; Shu, T. A non-nitric acid method of adipic acid synthesis: Organic solvent- and promoter-free oxidation of cyclohexanone with oxygen over hollow-structured Mn/TS-1 catalysts. Green Chem. 2015, 17, 1884-1892. [CrossRef]

22. Givirovskiy, G.; Ruuskanen, V.; Väkiparta, T.; Ahola, J. Electrocatalytic performance and cell voltage characteristics of 1st-row transition metal phosphate (TM-Pi) catalysts at neutral pH. Mater. Today Energy 2020, 17, 100426. [CrossRef]

23. Shen, Y.; Liu, J.; Jiang, J.; Liu, A.B.; Dong, S. Fabrication of a Metalloporphyrin-Polyoxometalate Hybrid Film by a Layer-by-Layer Method and Its Catalysis for Hydrogen Evolution and Dioxygen Reduction. J. Phys. Chem. B 2003, 107, 9744-9748. [CrossRef]

24. Huang, M.; Bi, L.; Shen, Y.; Liu, A.B.; Dong, S. Nanocomposite Multilayer Film of Preyssler-Type Polyoxometalates with Fine Tunable Electrocatalytic Activities. J. Phys. Chem. B 2004, 108, 9780-9786. [CrossRef] 